\title{
OFFICIAL PUBLICATION
}

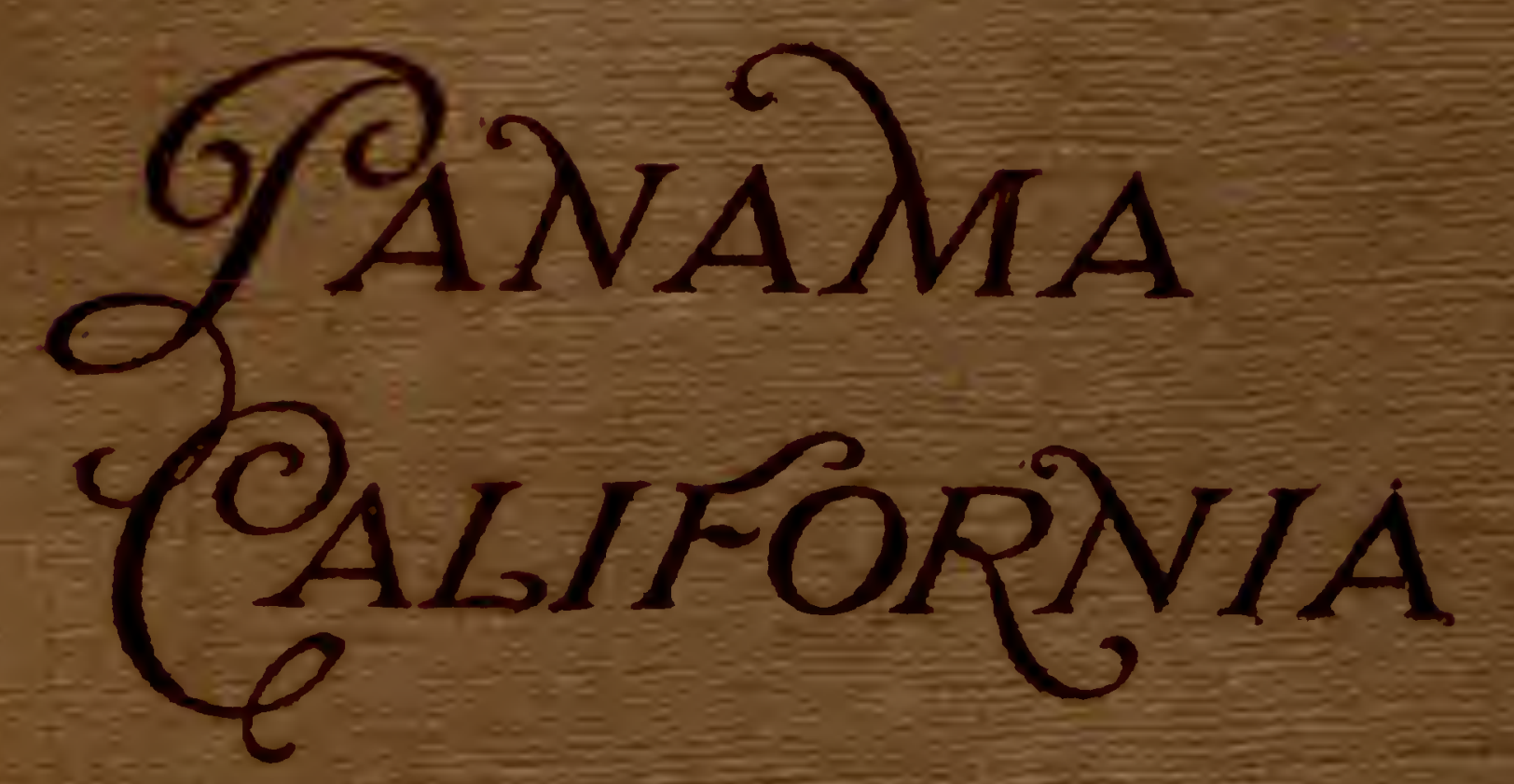

ENTR्रुATIONAS
ExPOSITION

1.7. SANDIsGO 1916

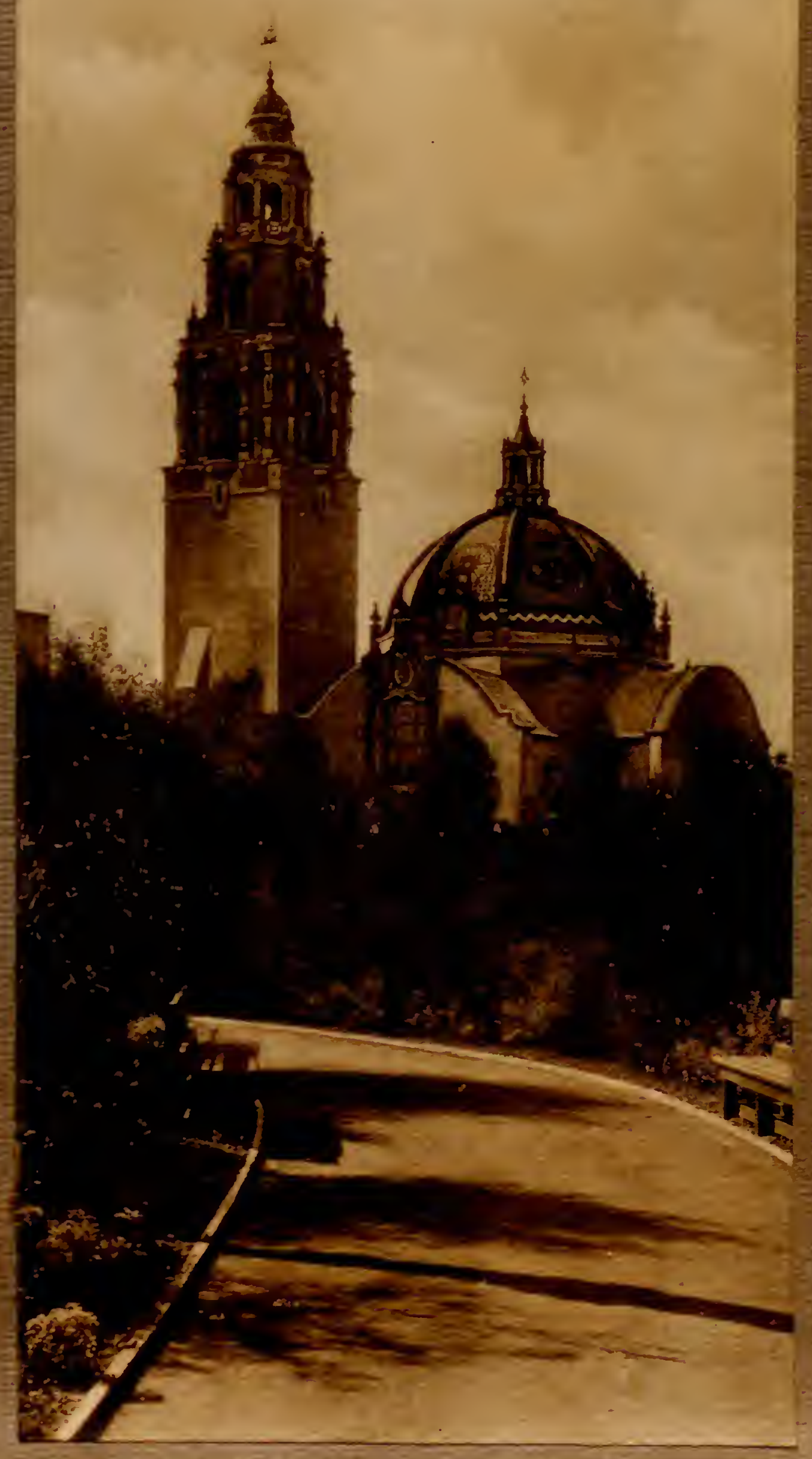





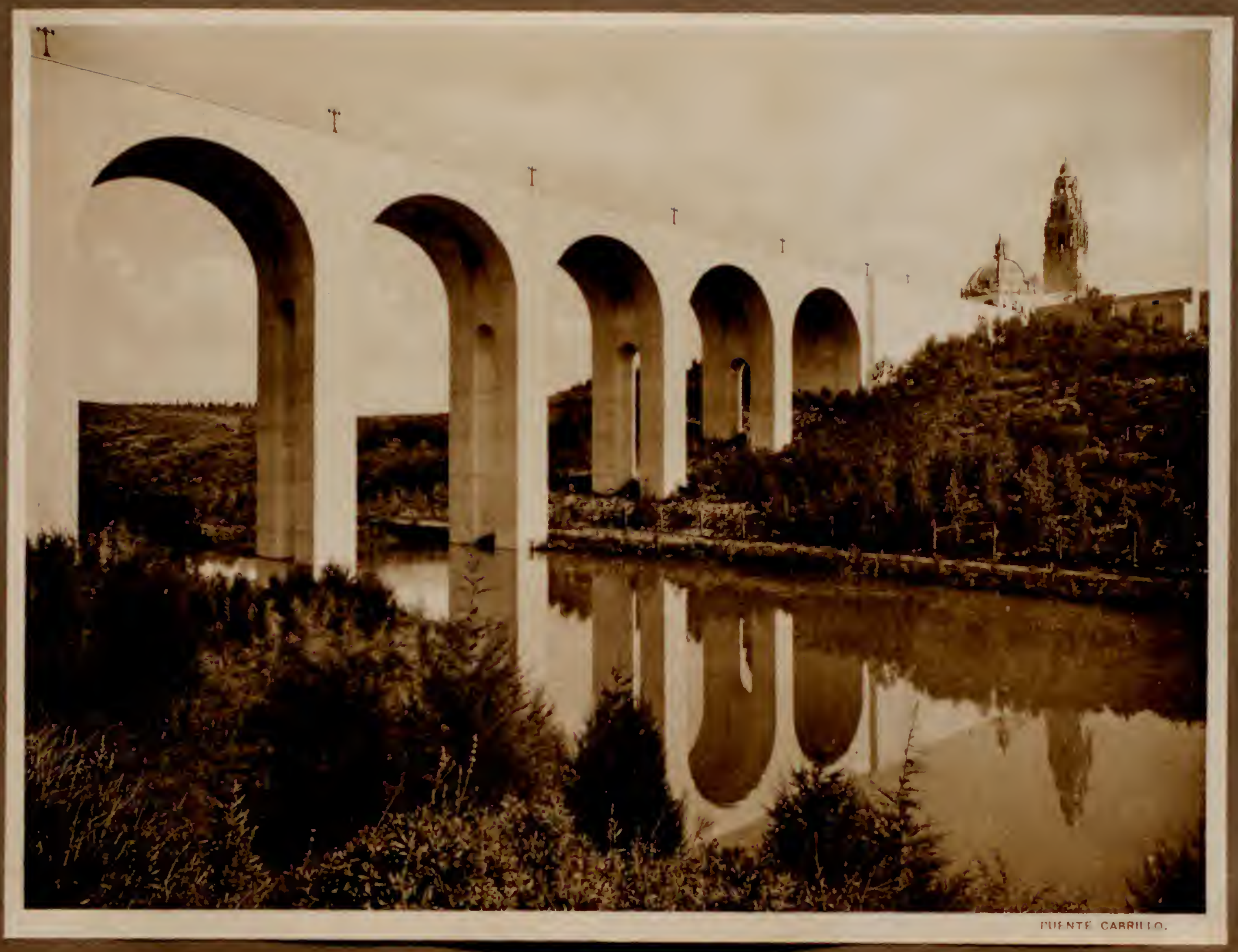





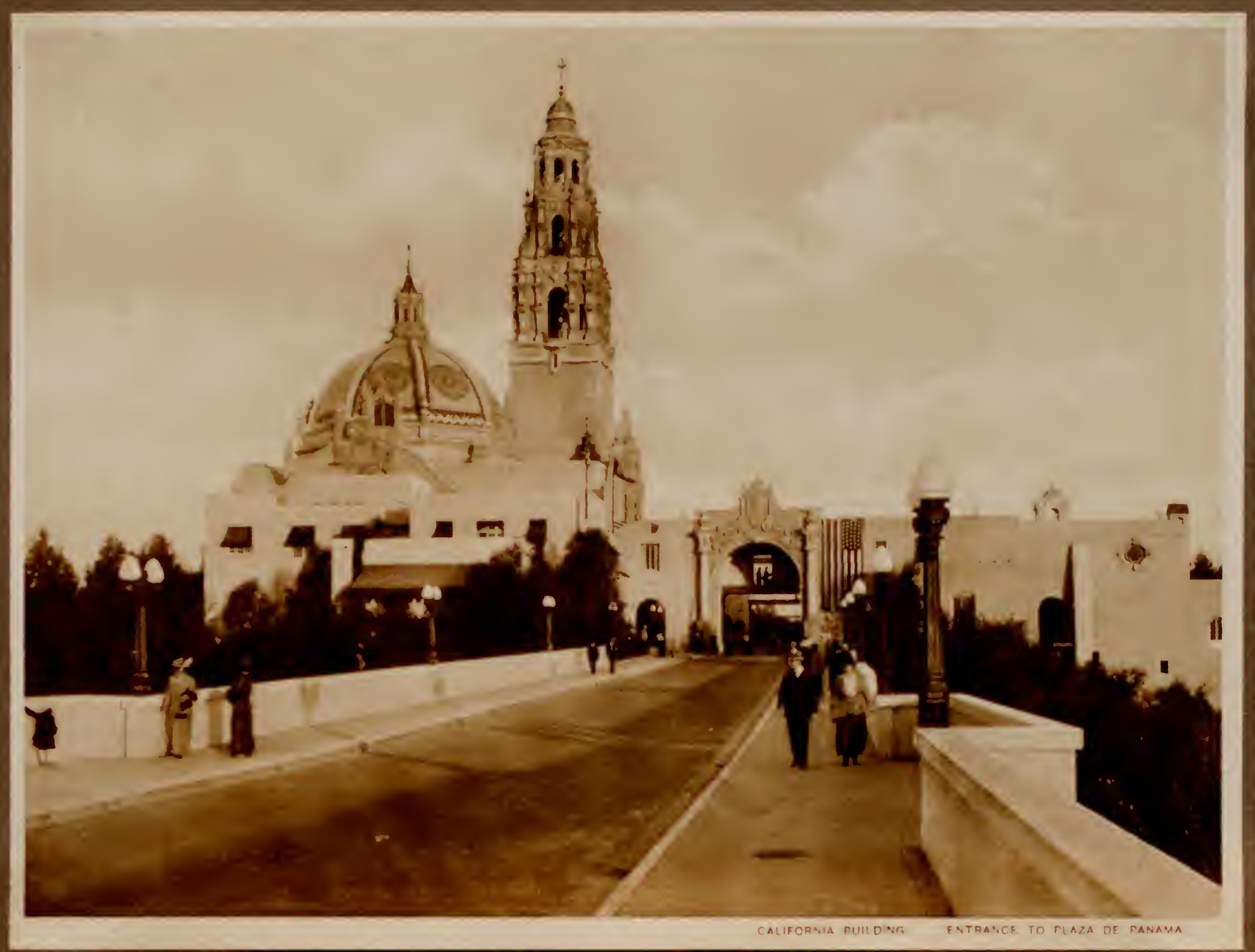





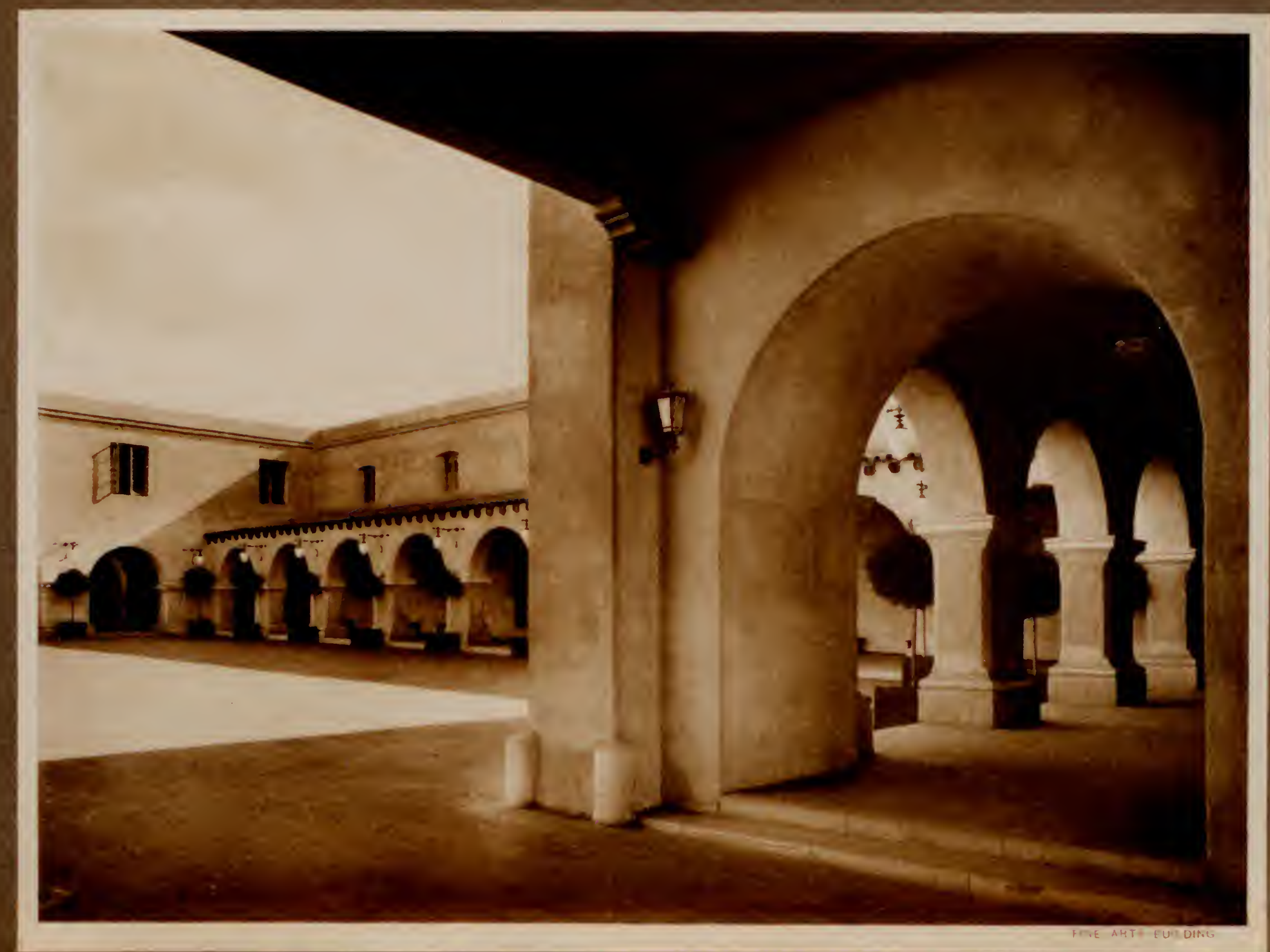





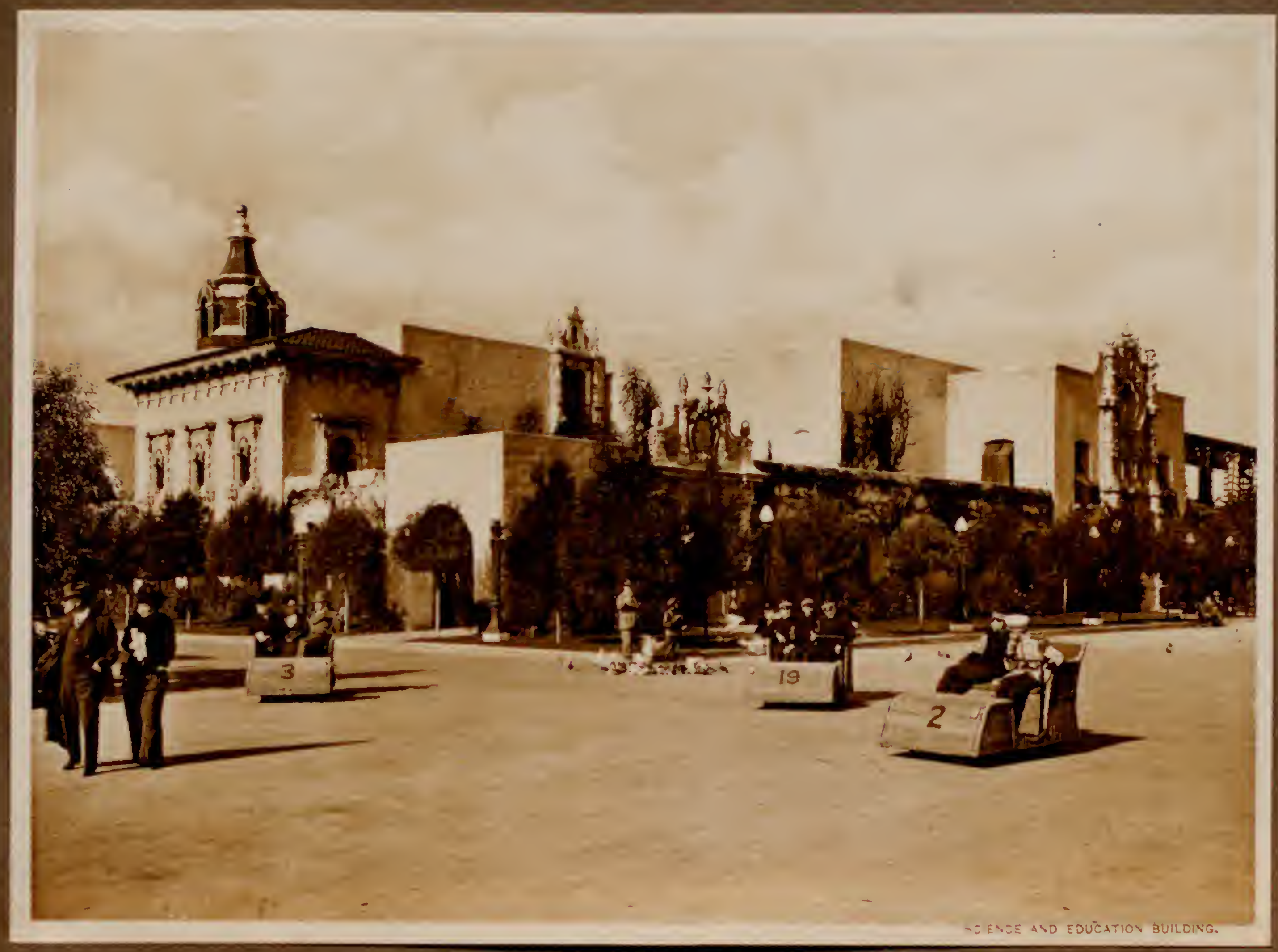





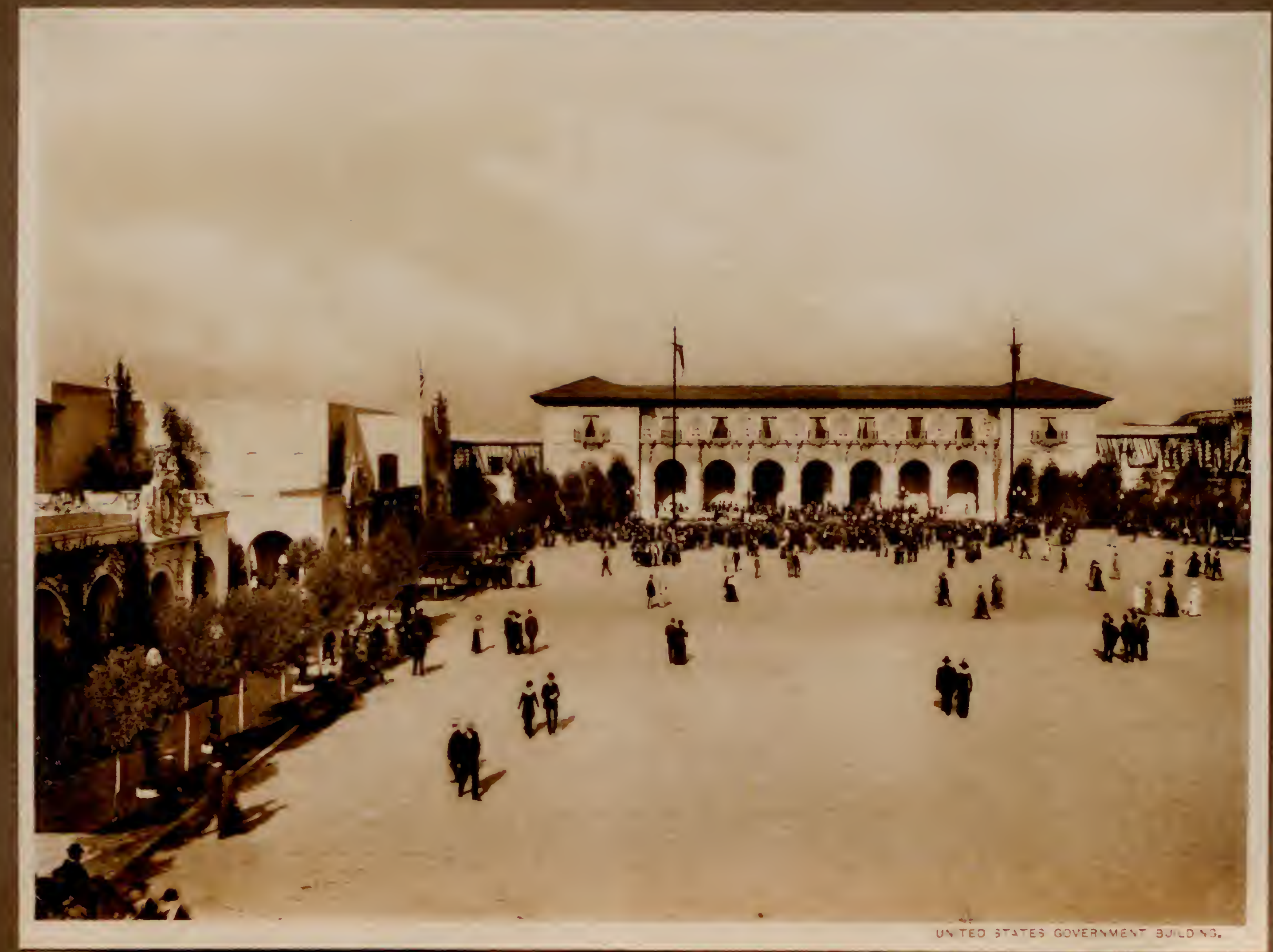





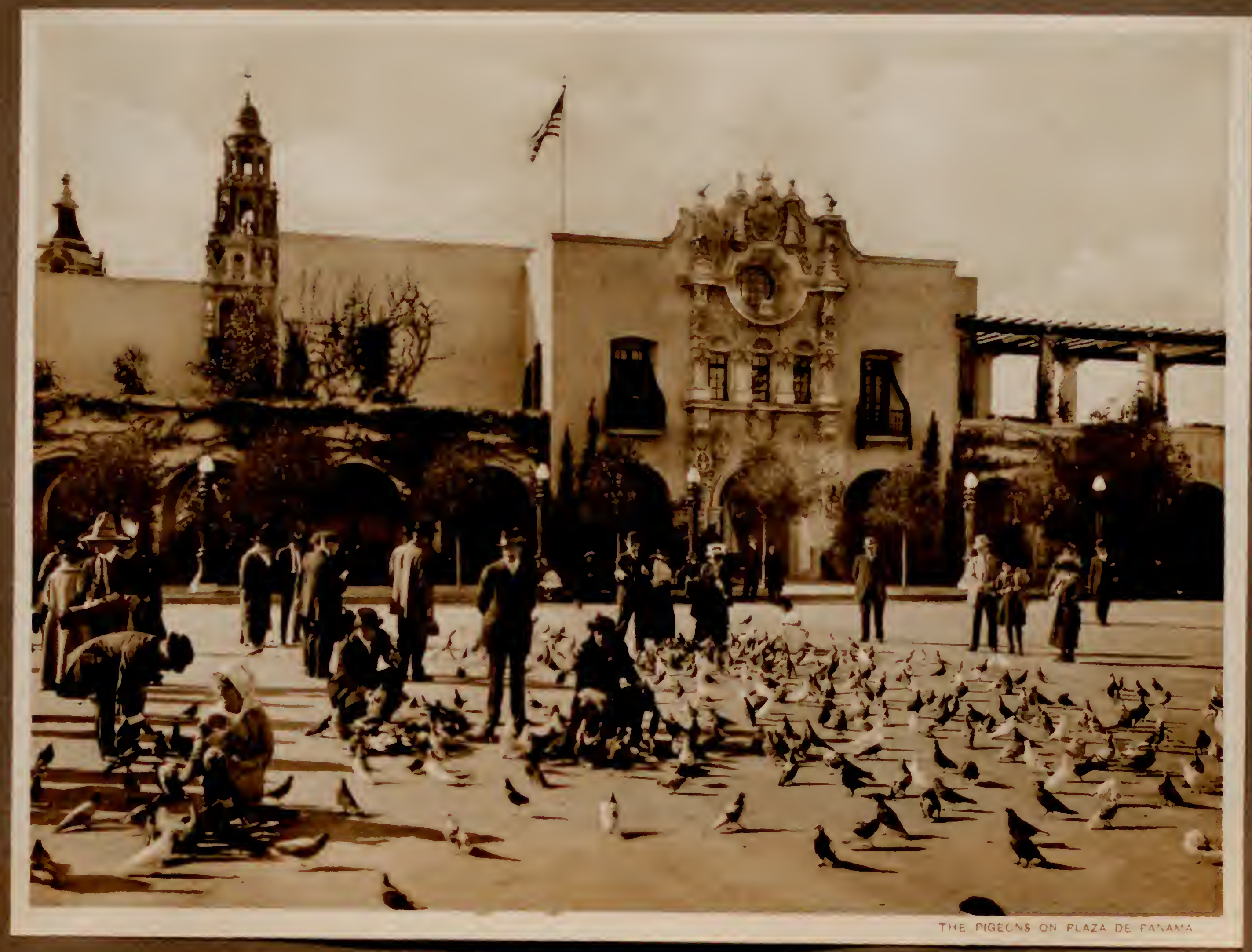





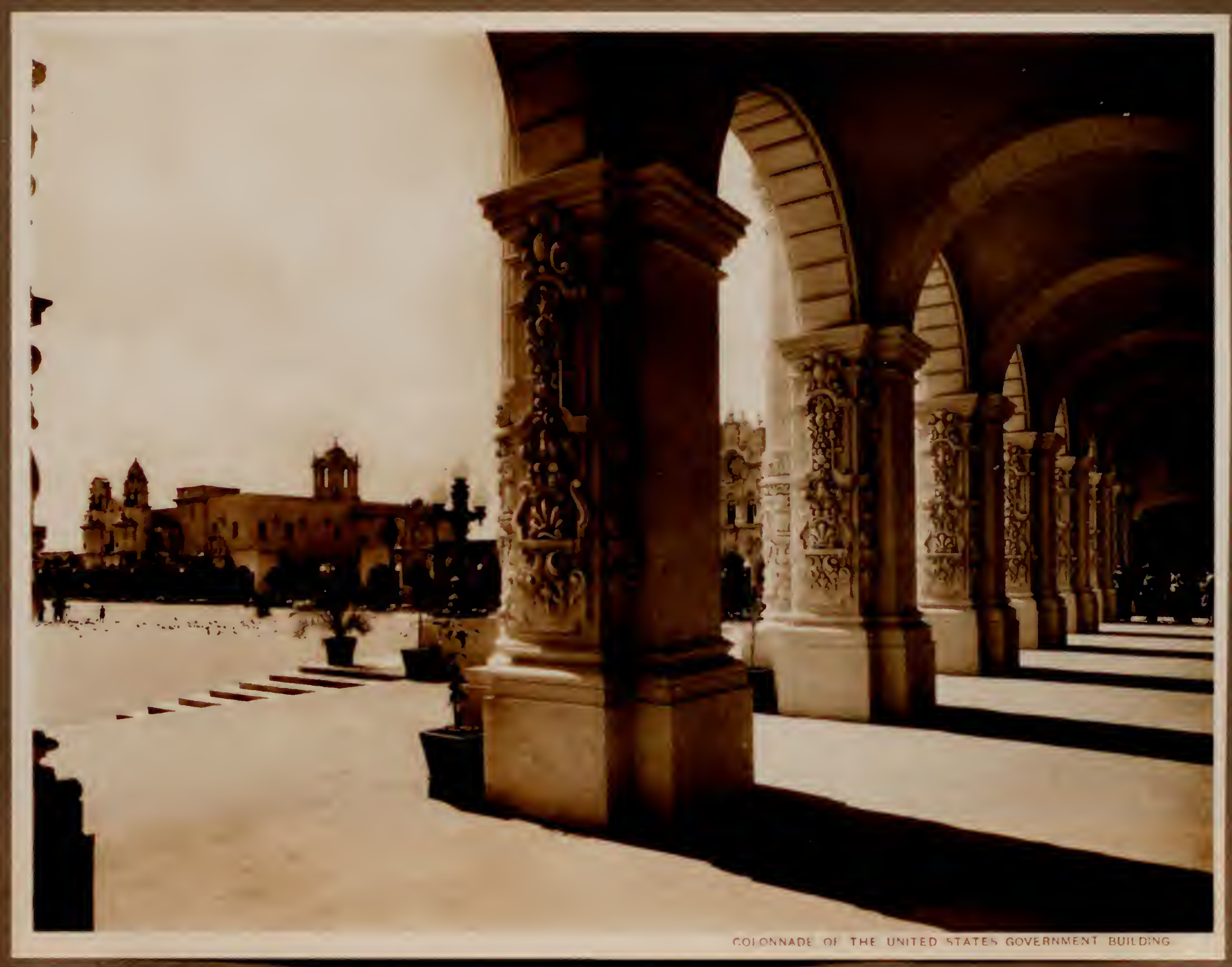





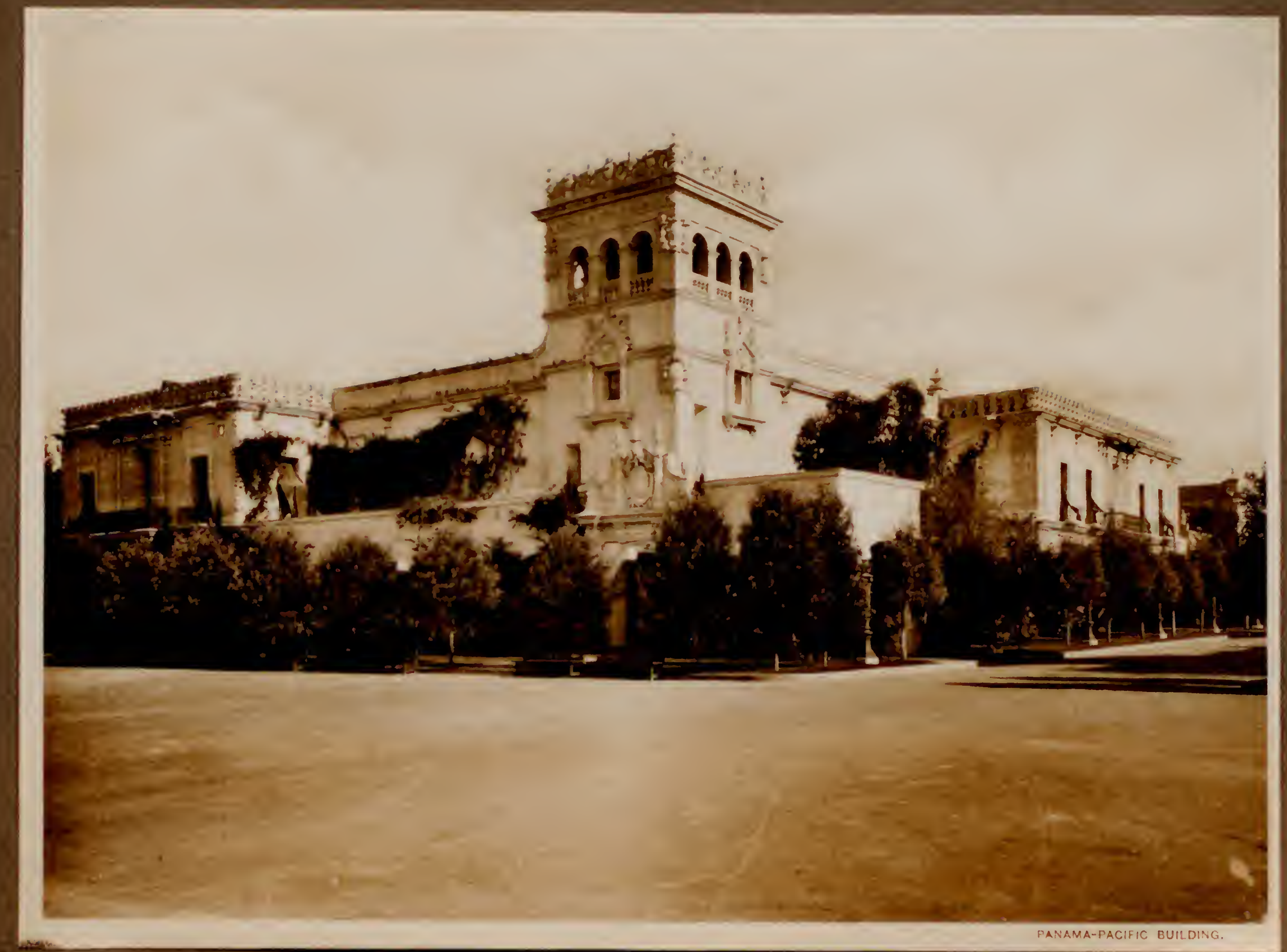





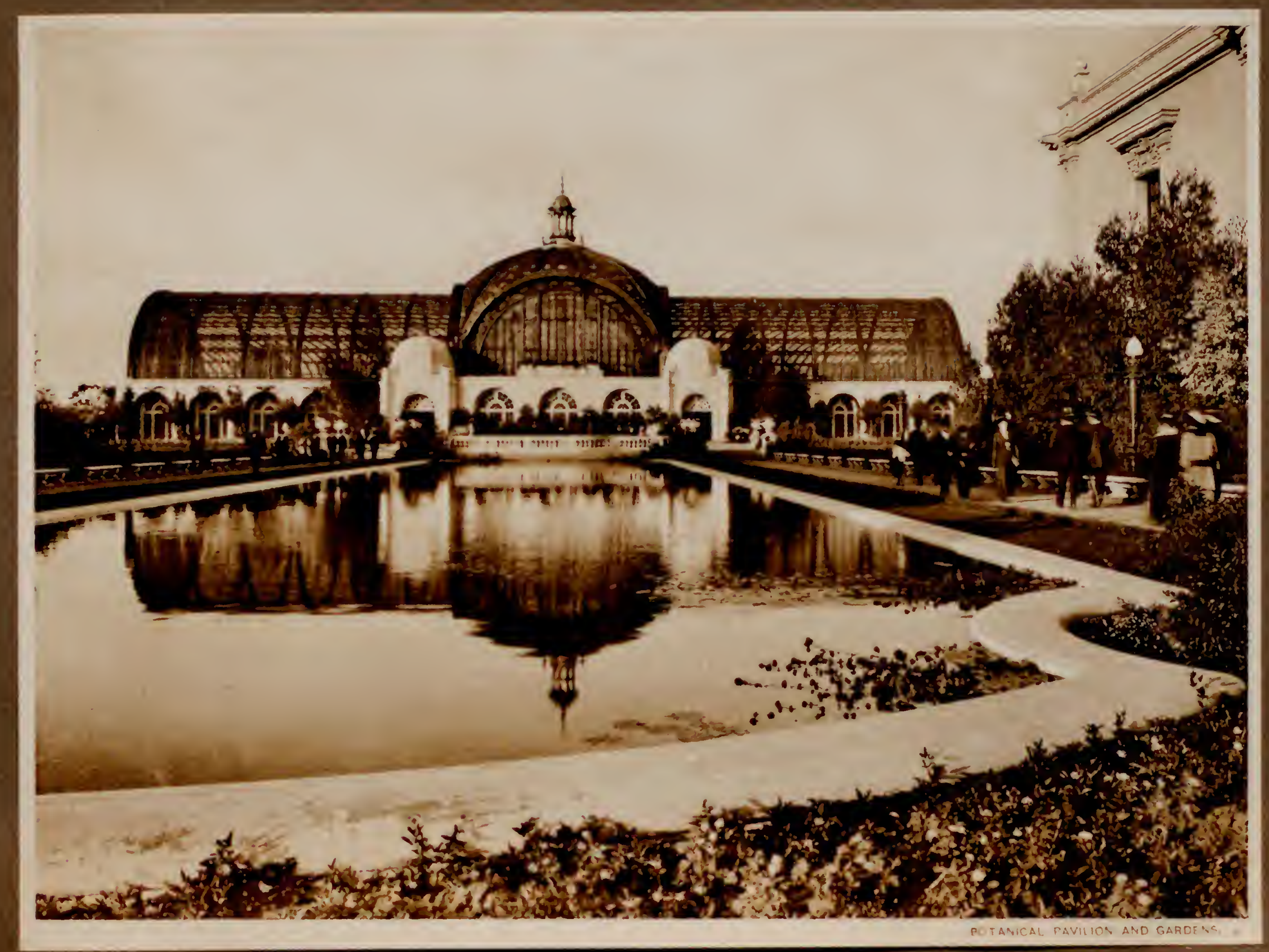





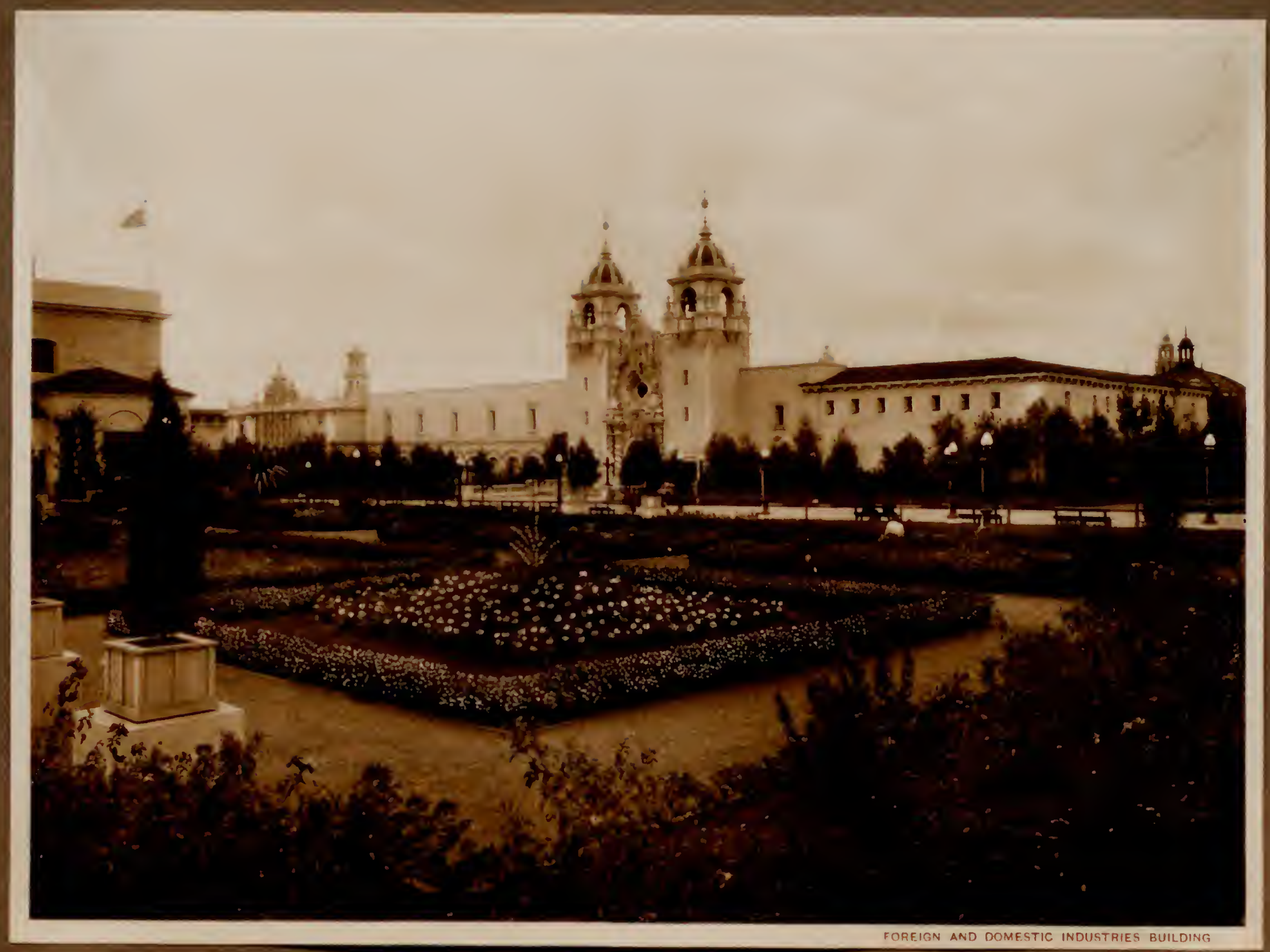




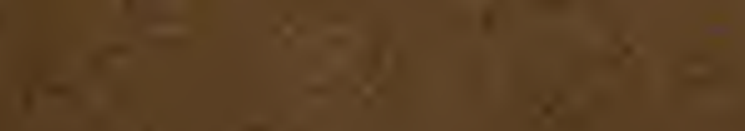




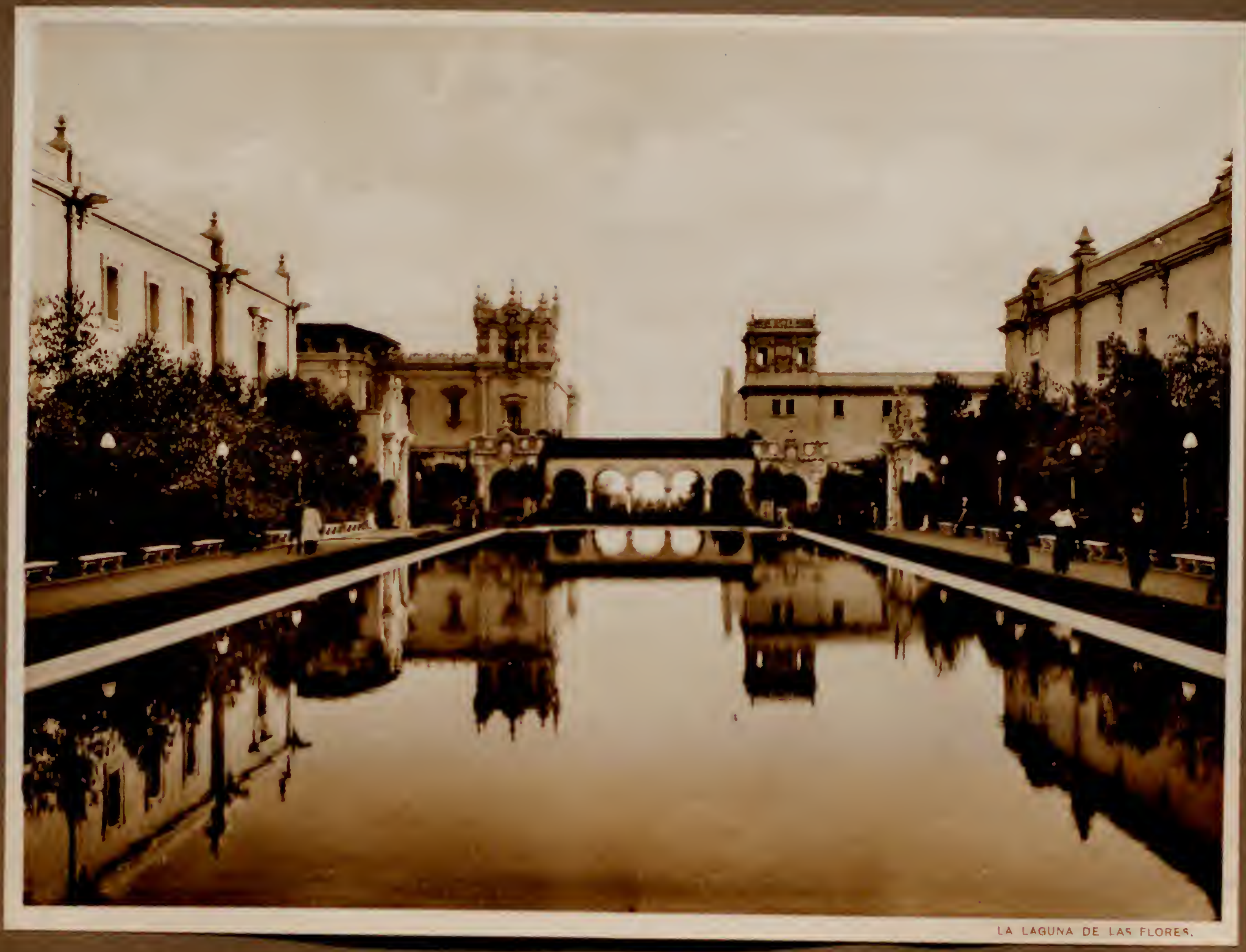





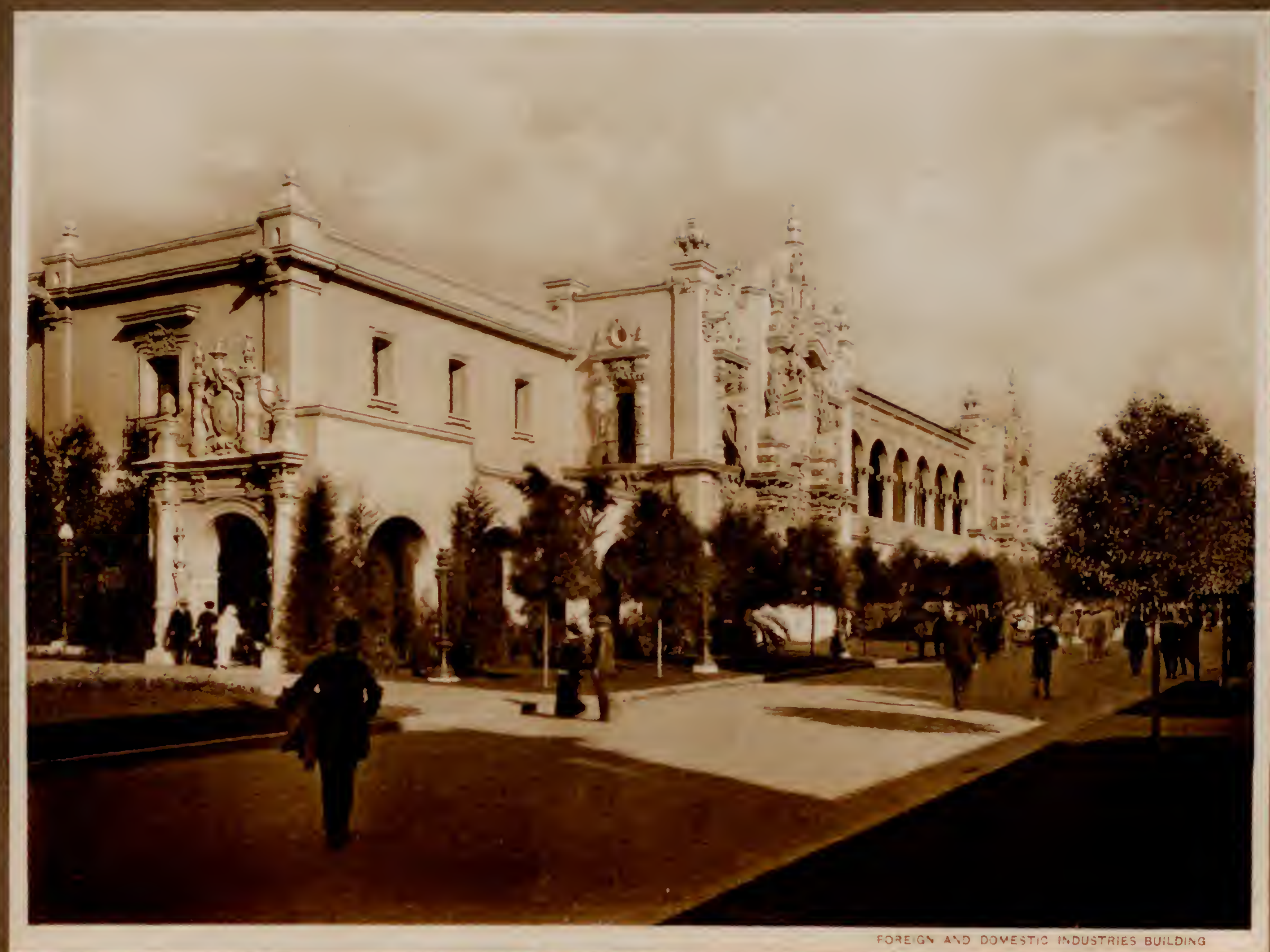





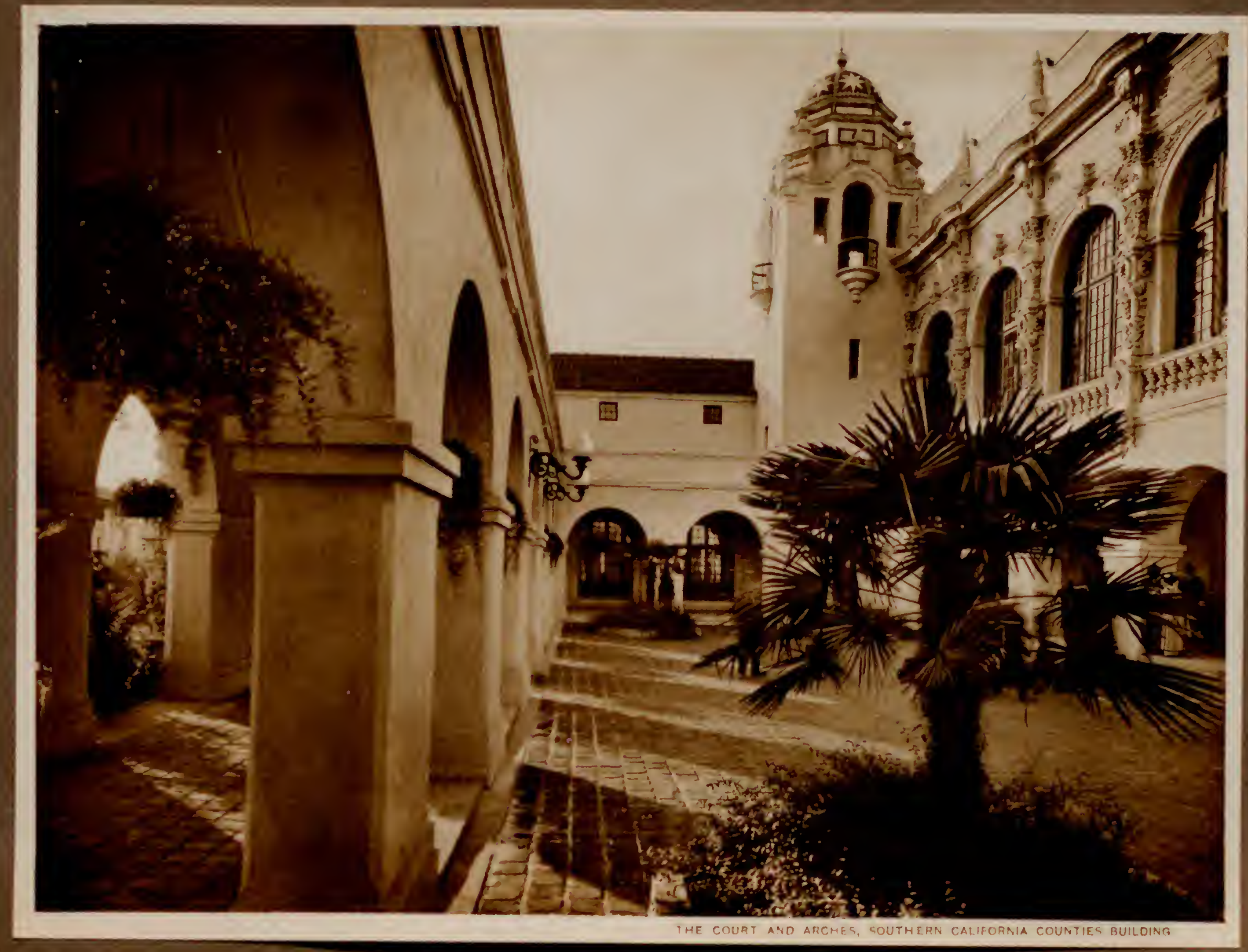




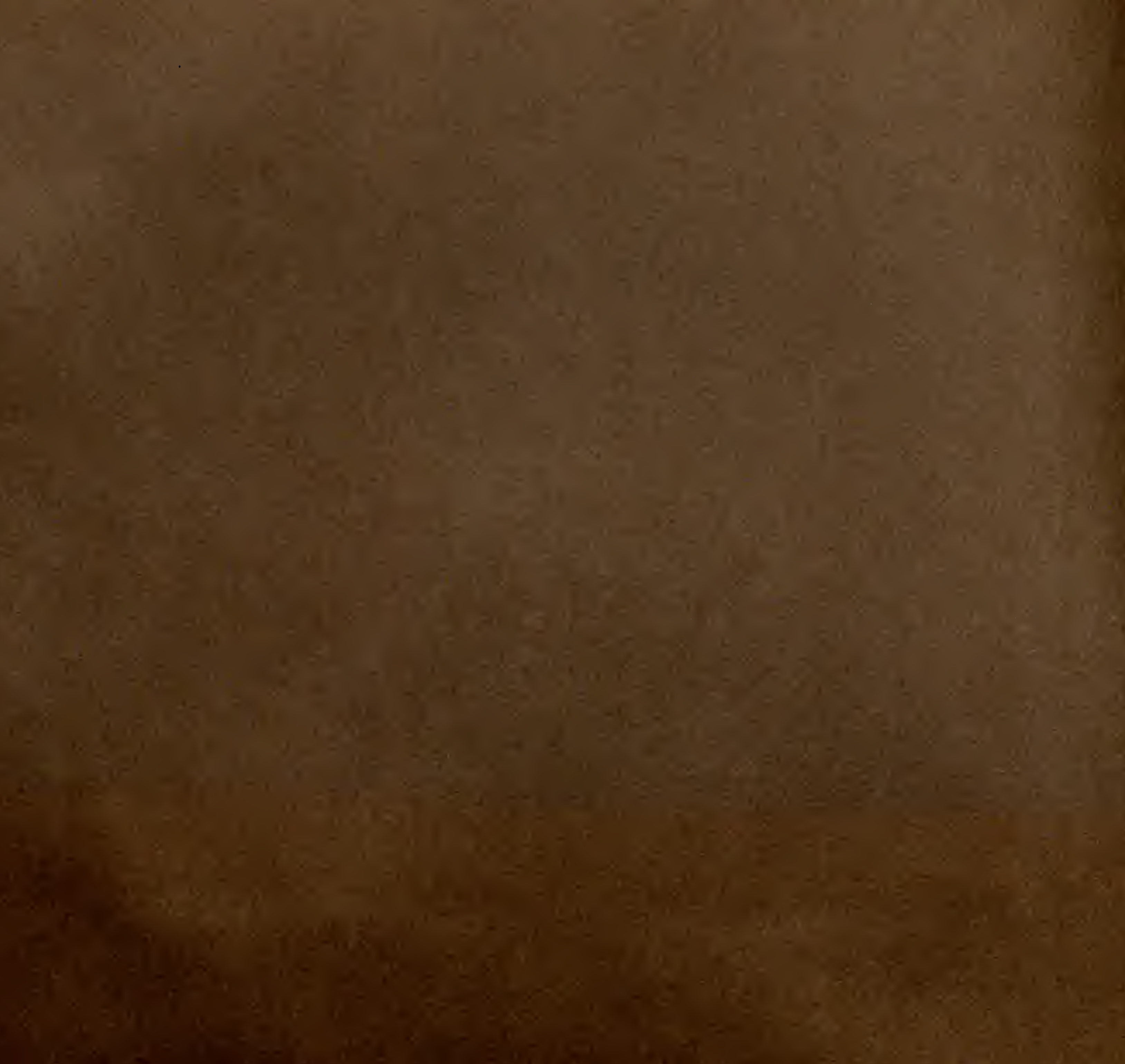




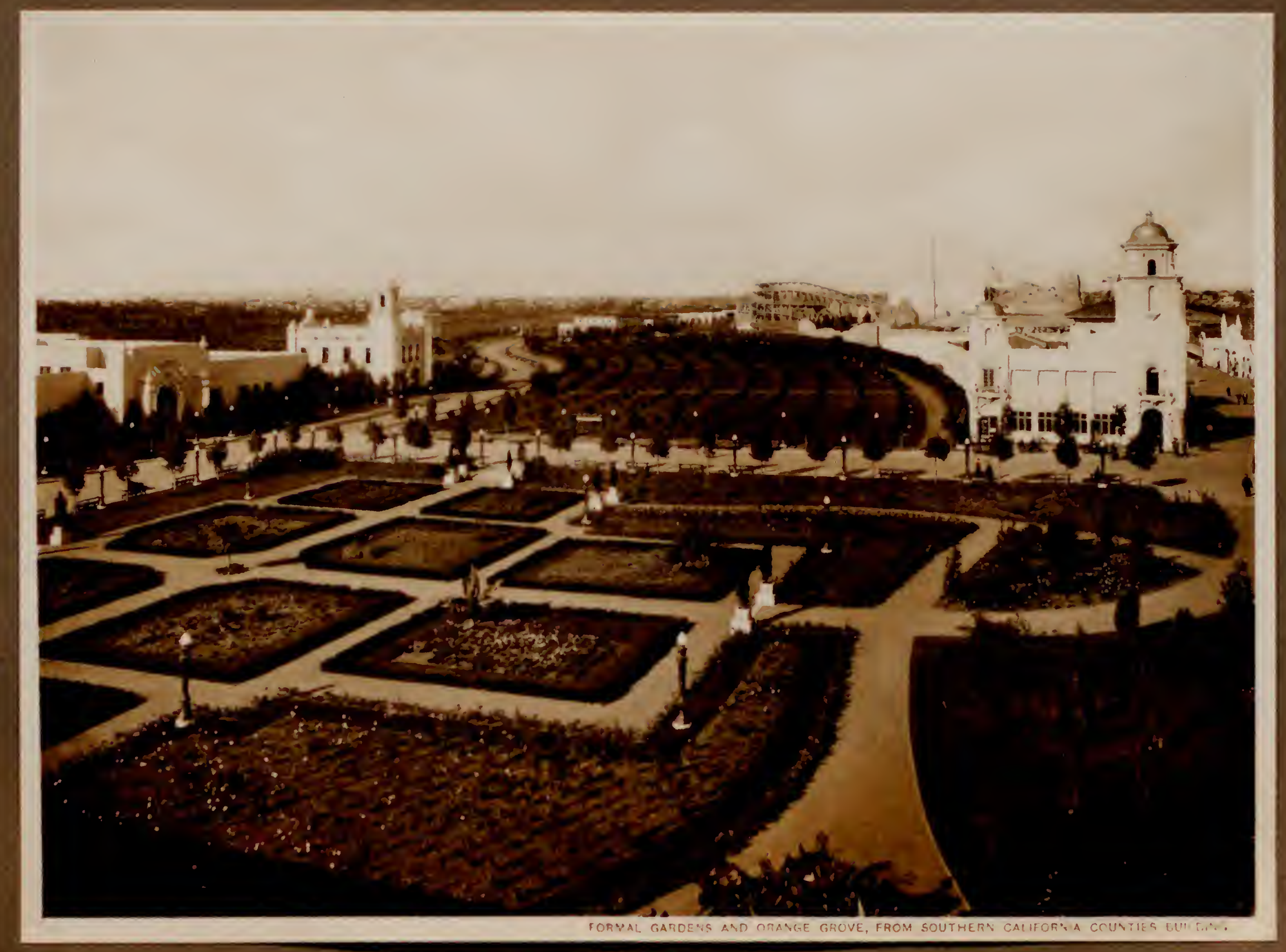




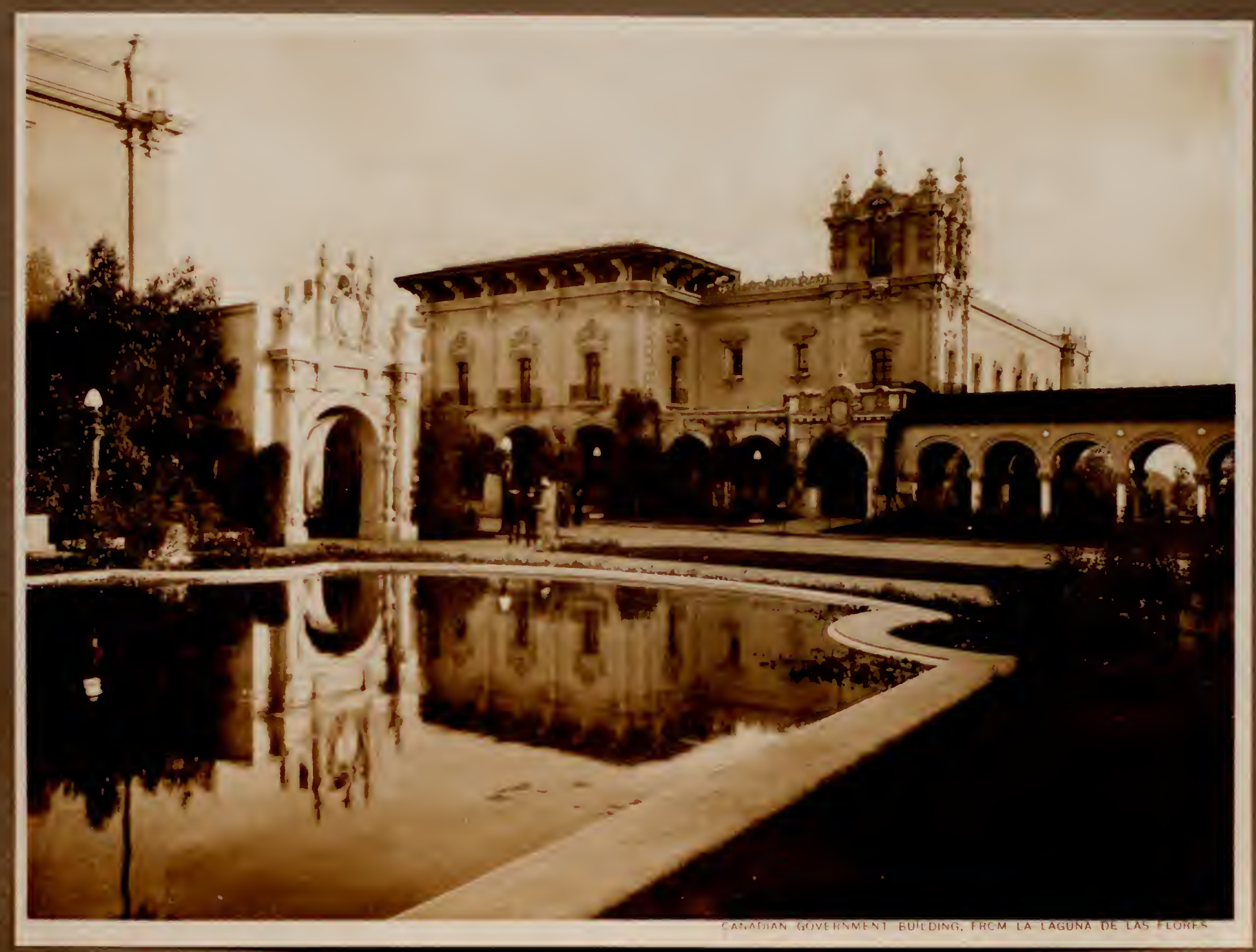


$36,2+175$

- $1-5=$ 


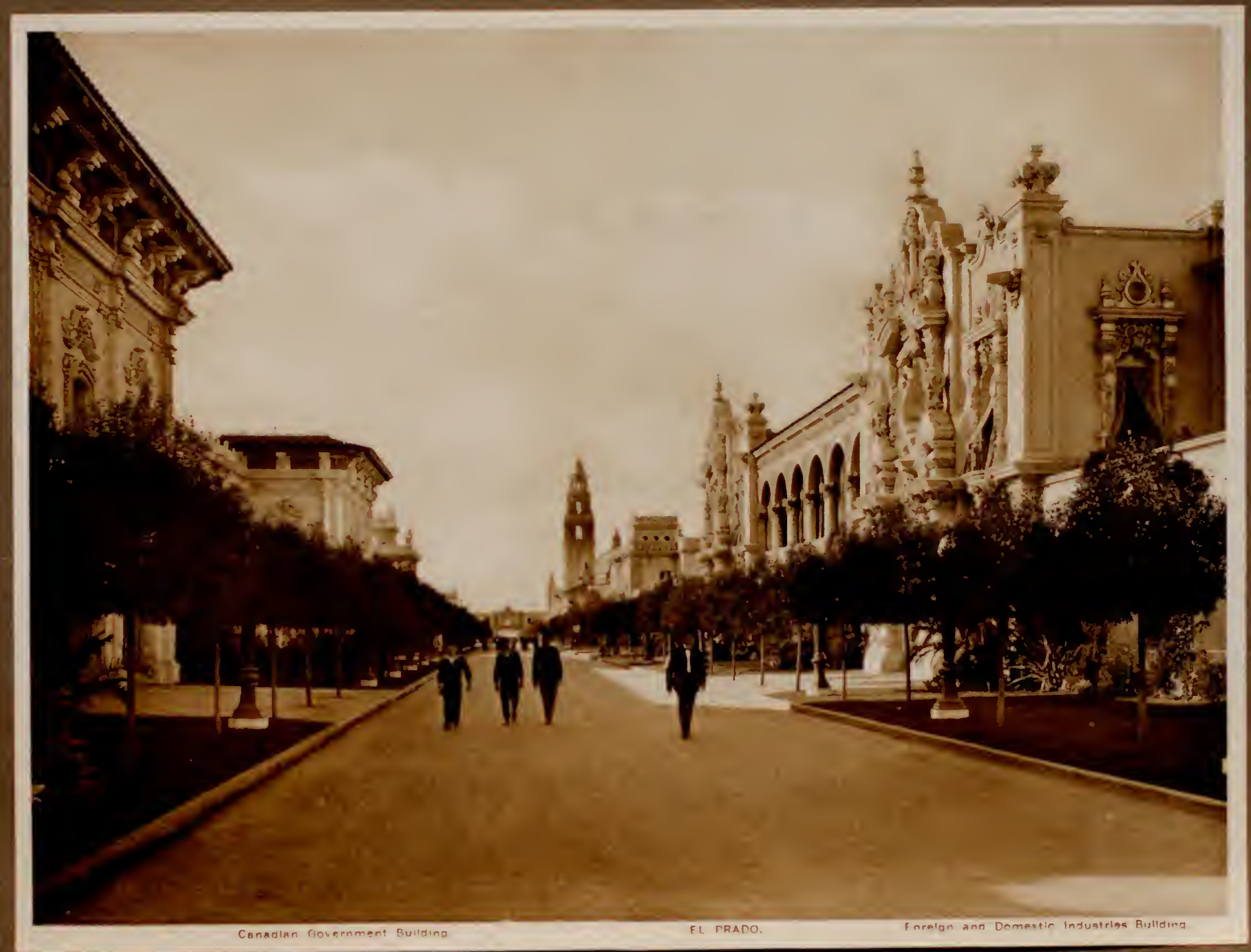




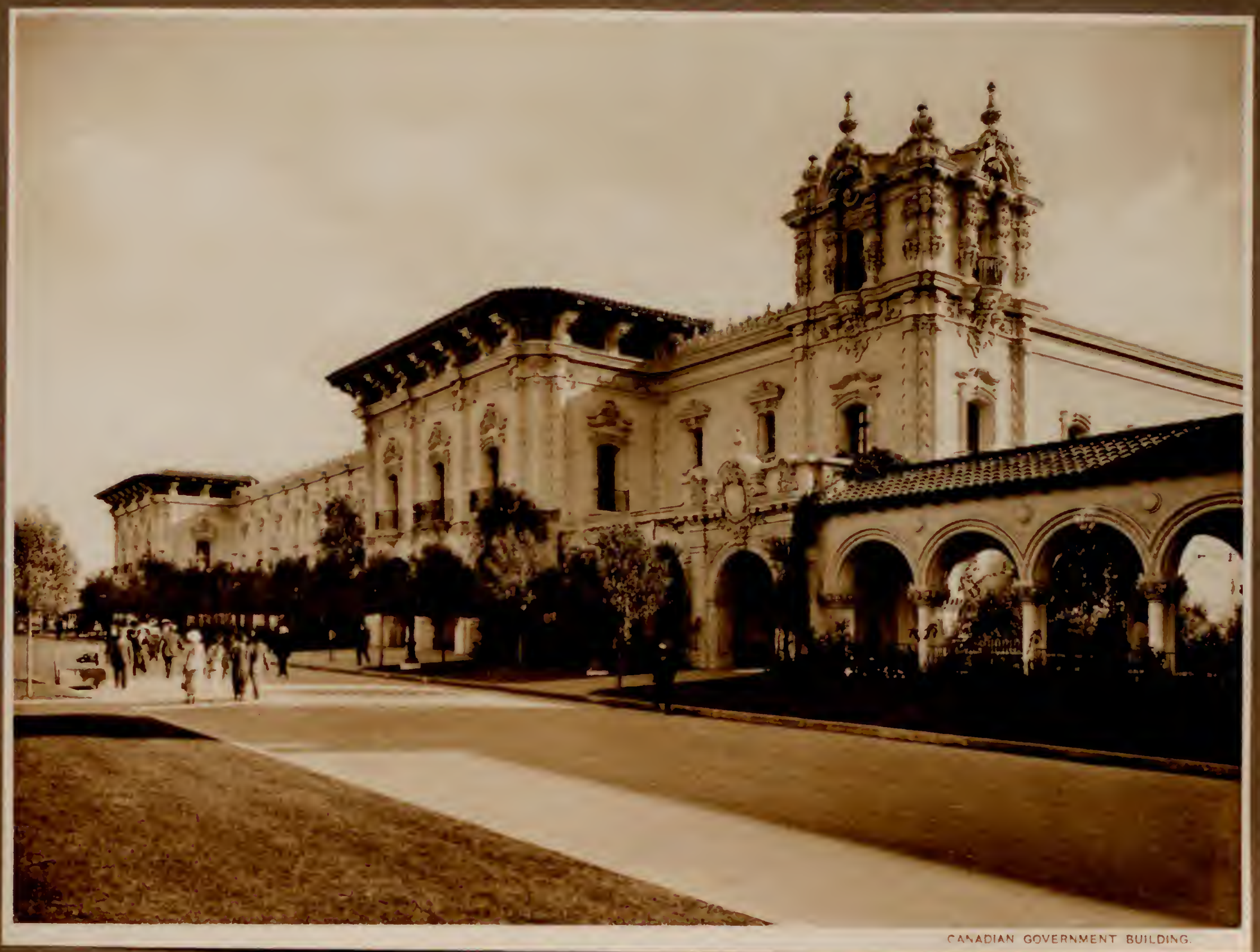





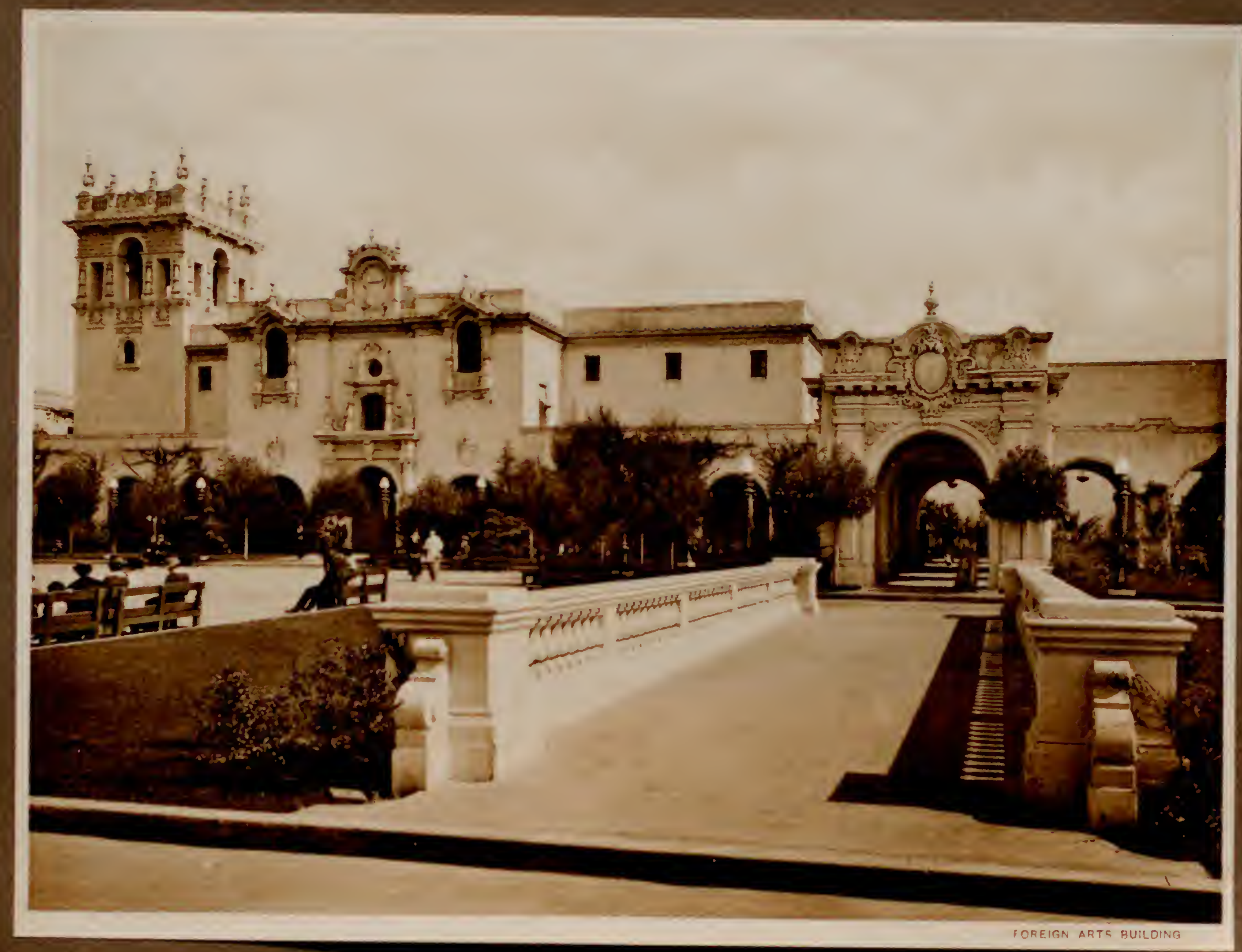





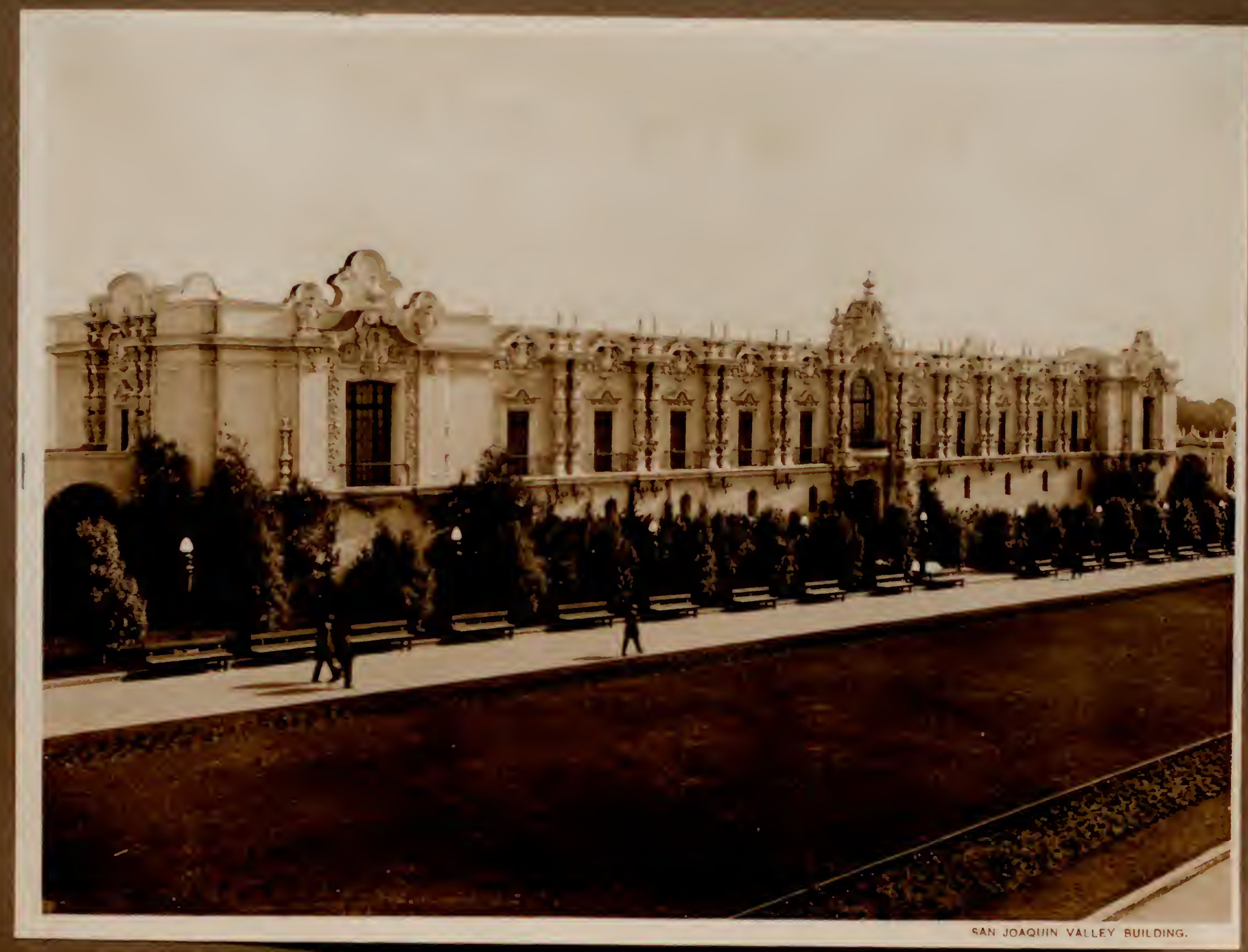


$+2$

논 $=x$

$(x-1)$

$3^{2}$

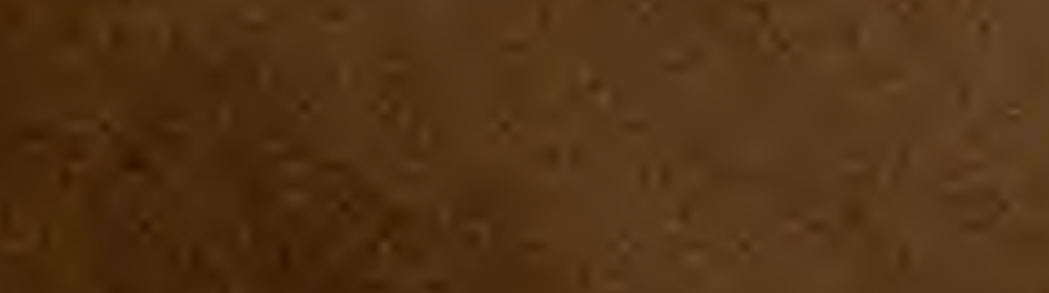

$\operatorname{nin}^{2}$

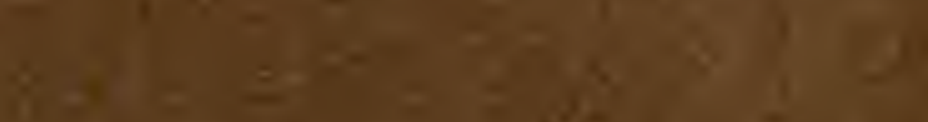

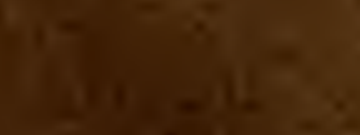




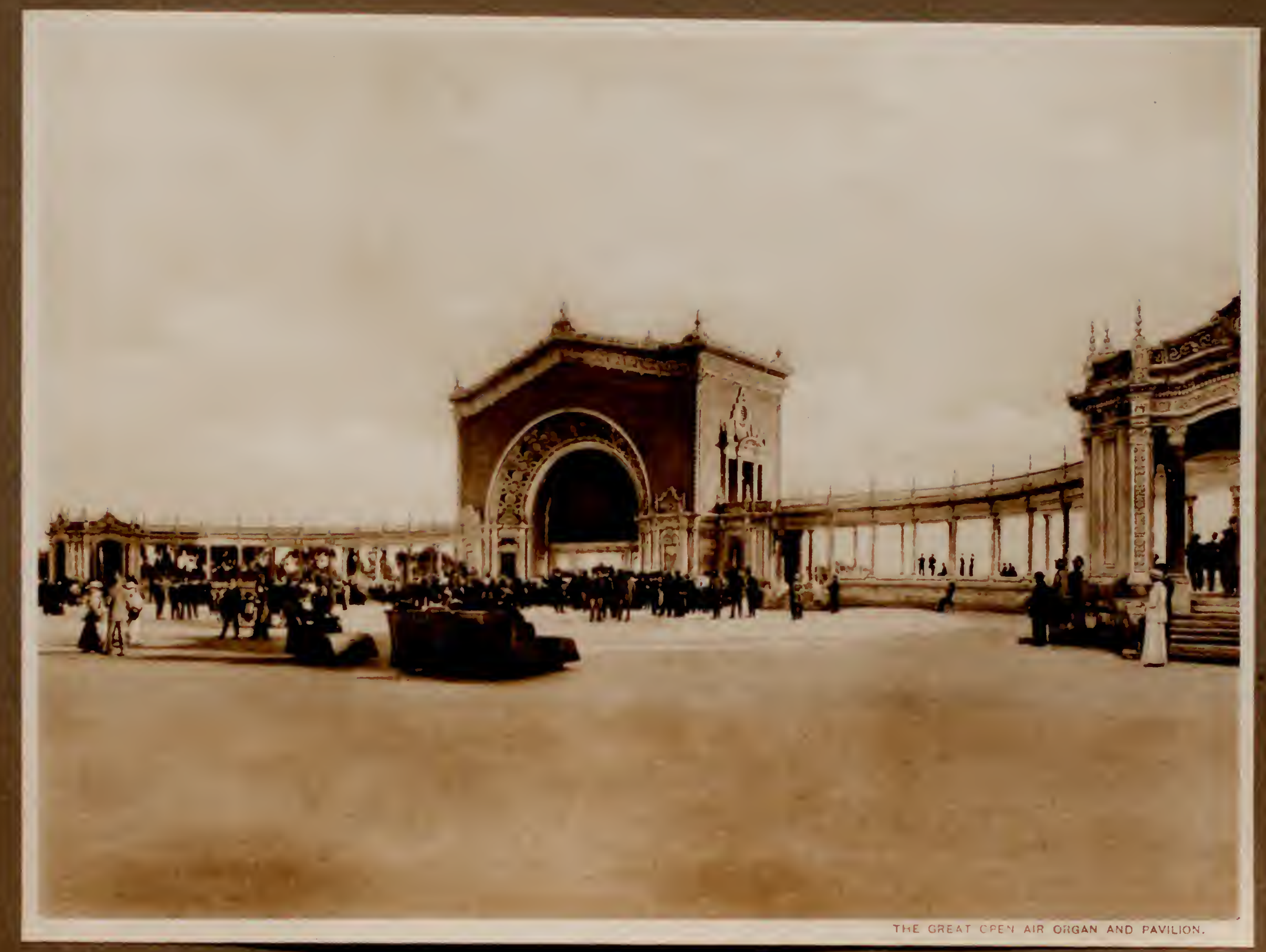


$16.5=$ 


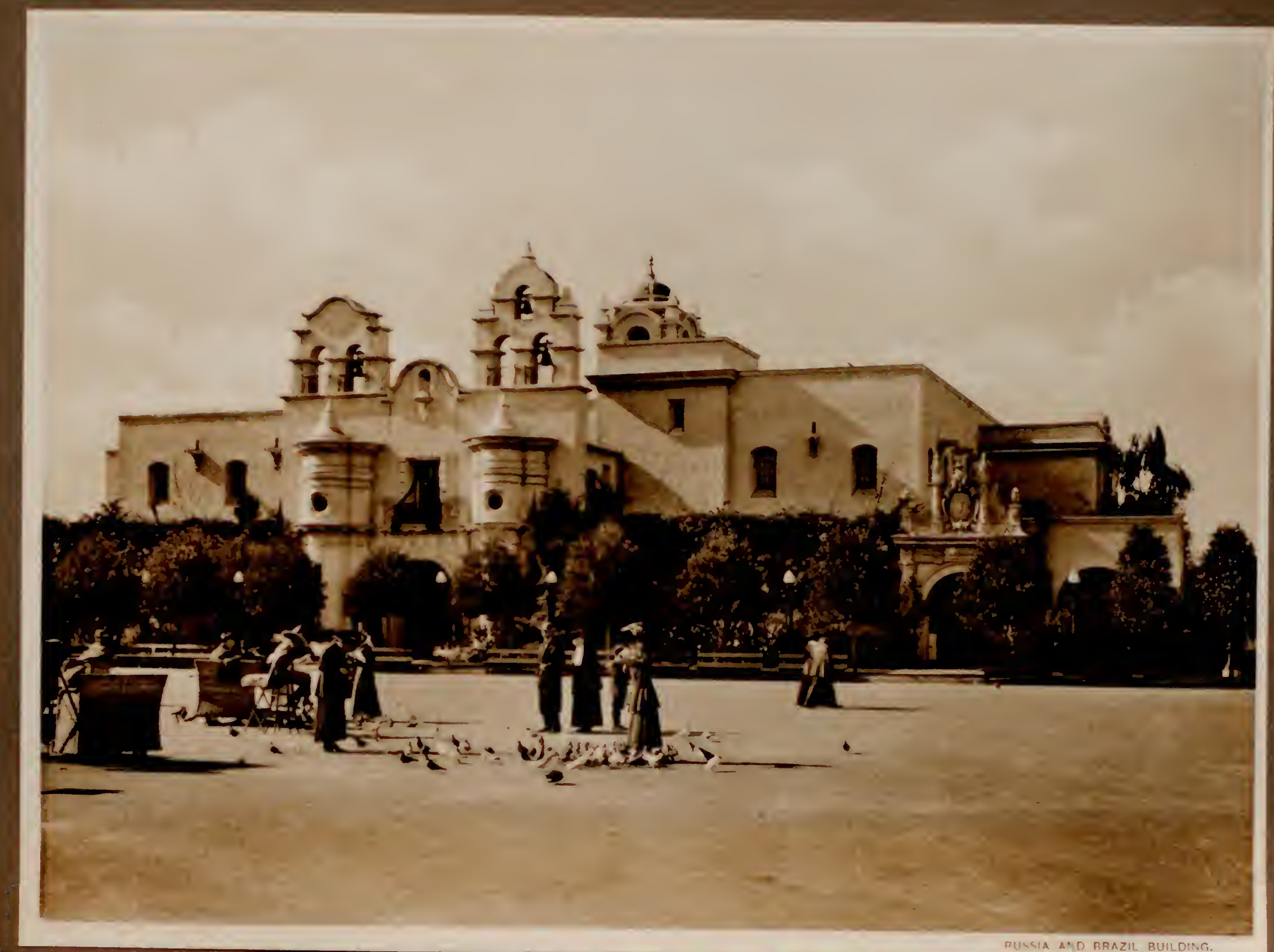





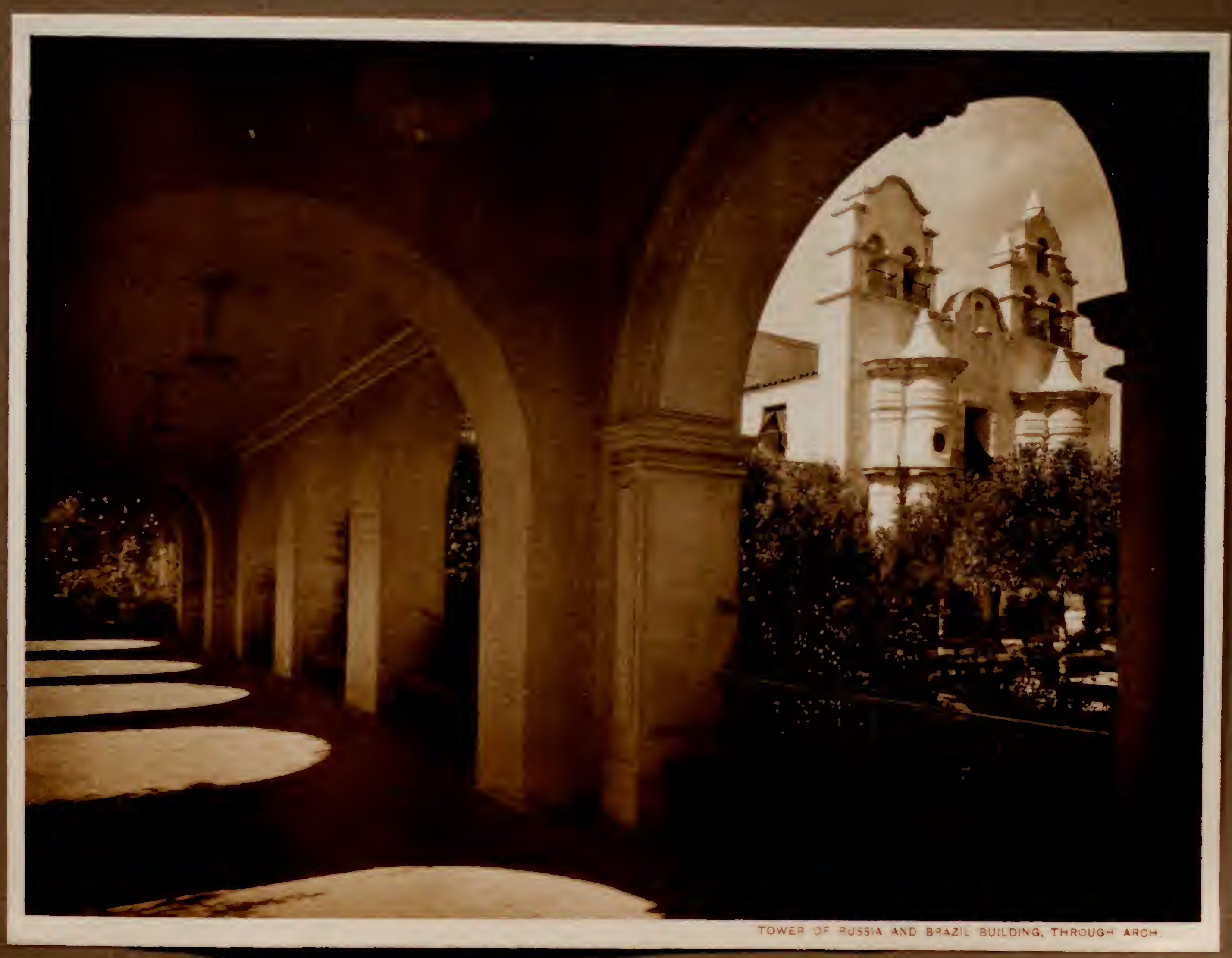



$x^{-12}$

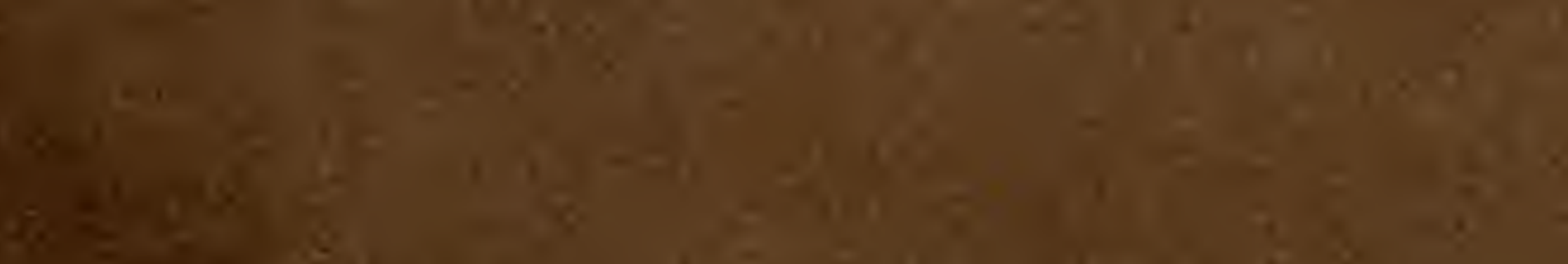




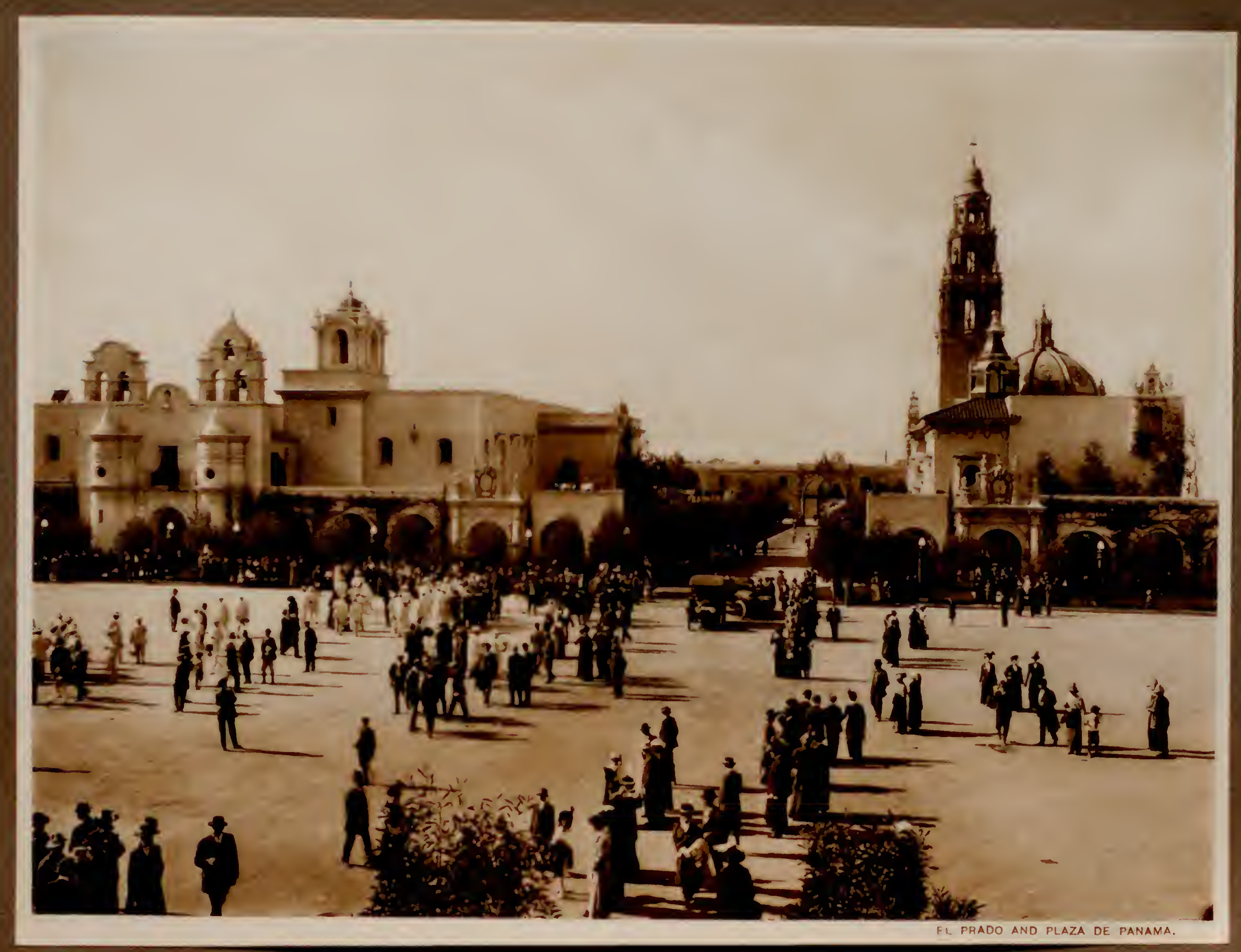





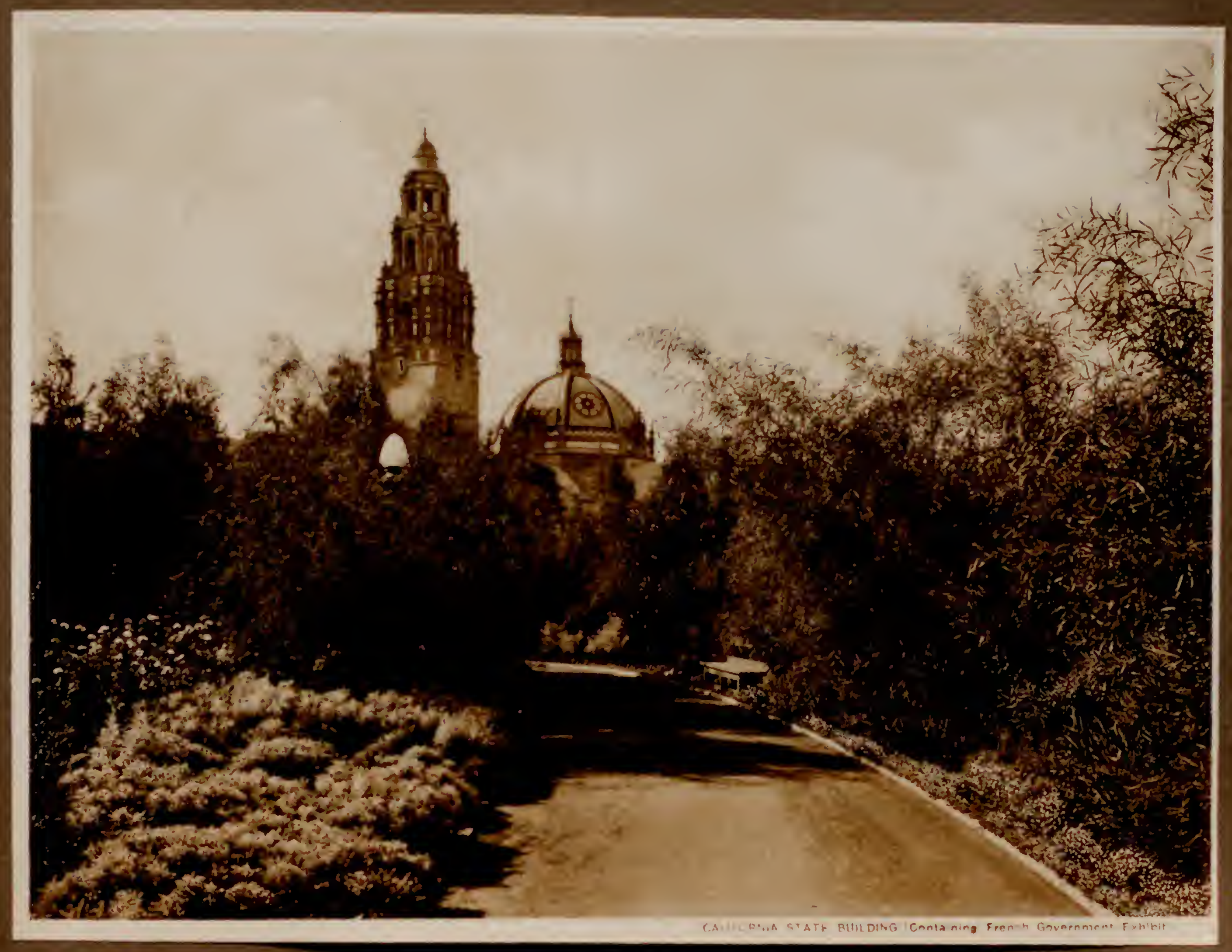




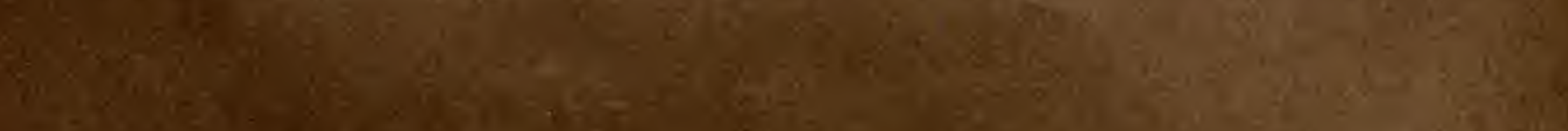

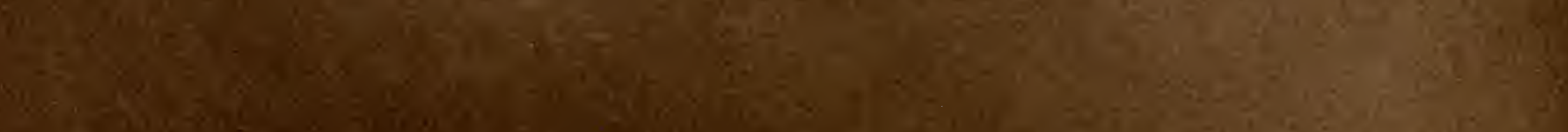




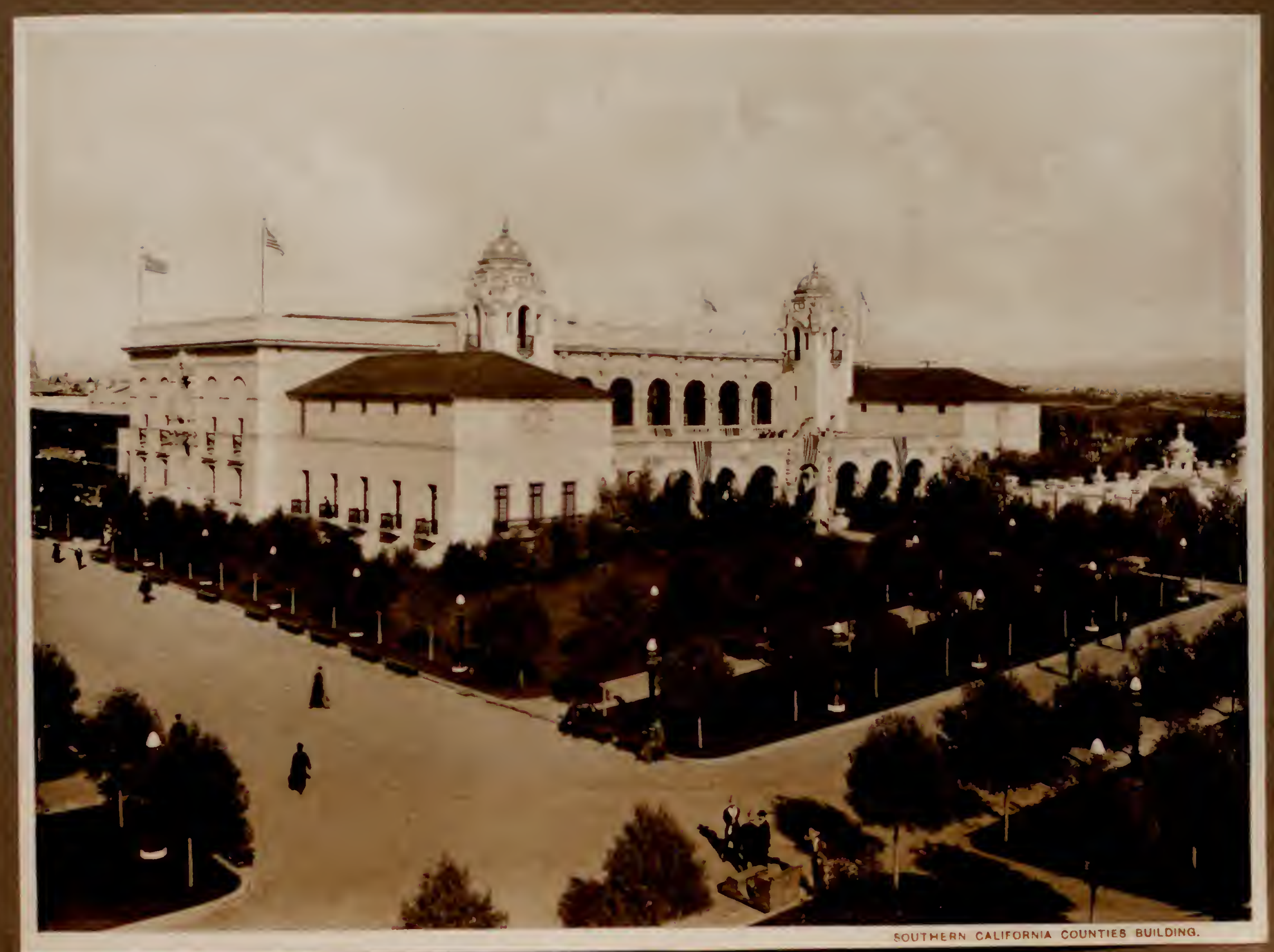




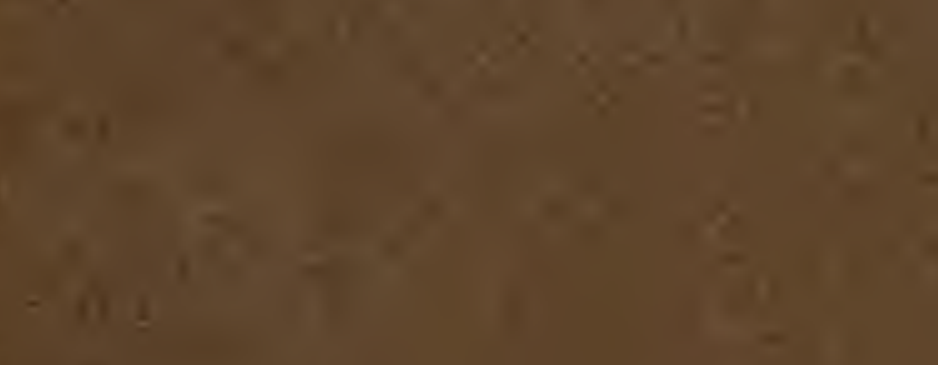

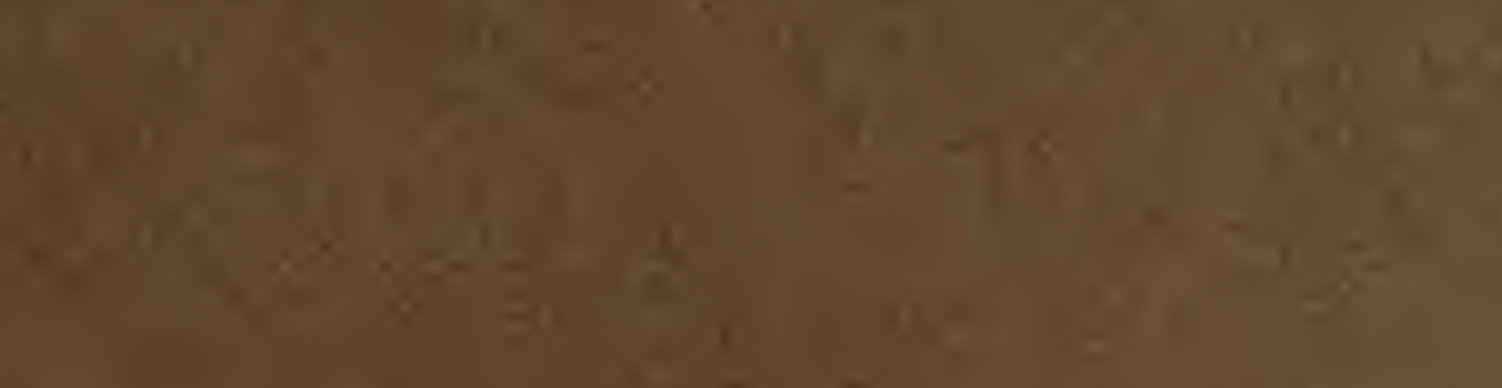




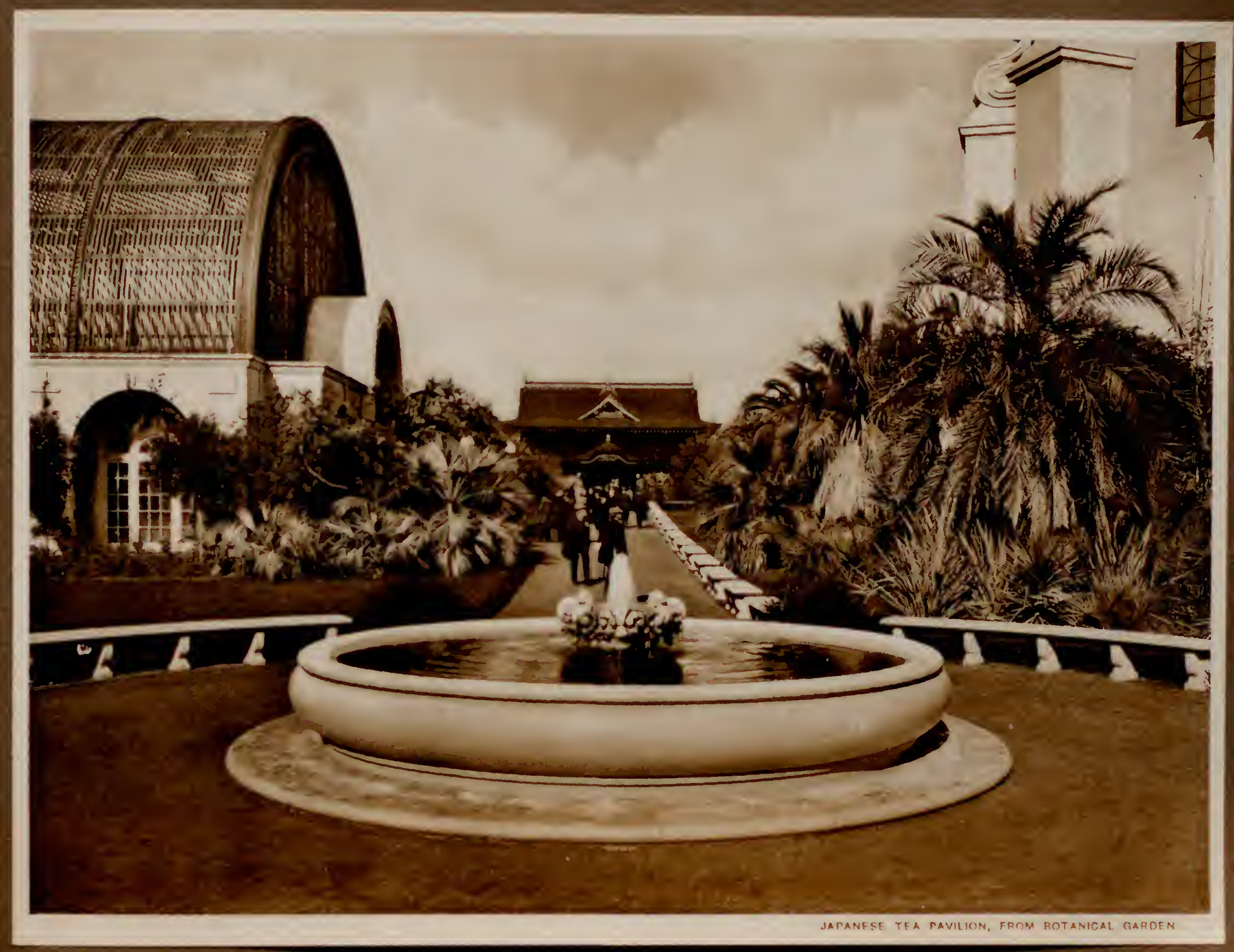


$x \rightarrow \frac{10}{x+15}$

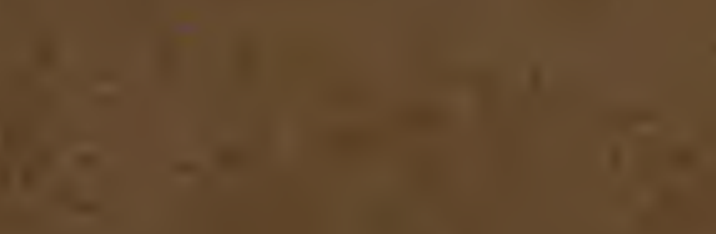

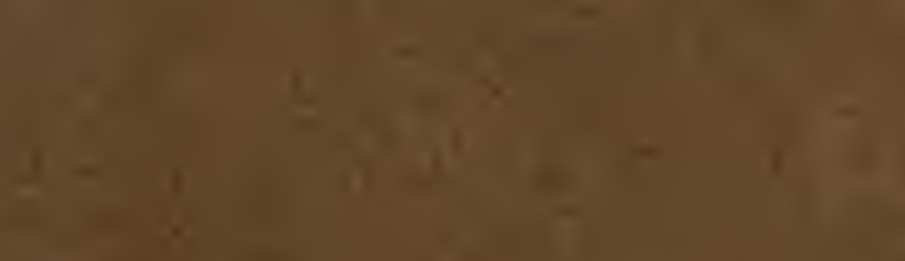

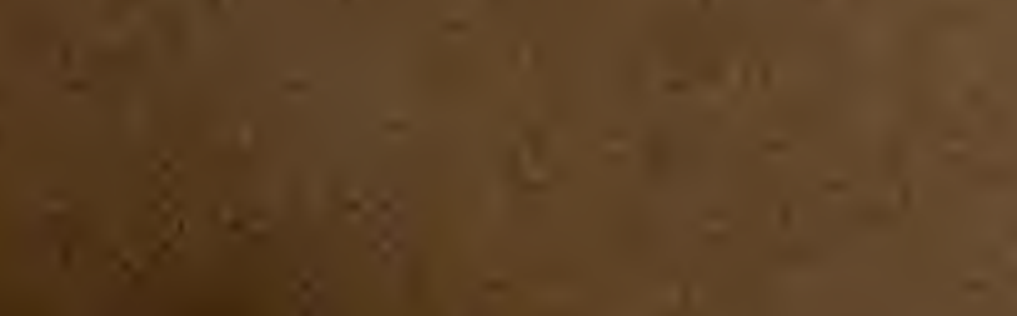

$x-8$

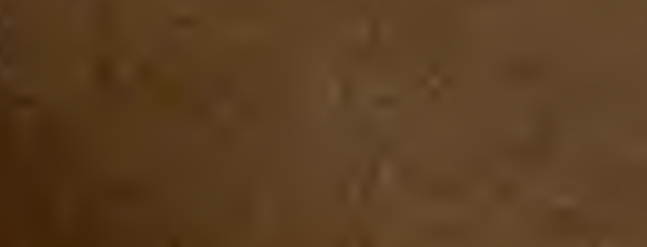

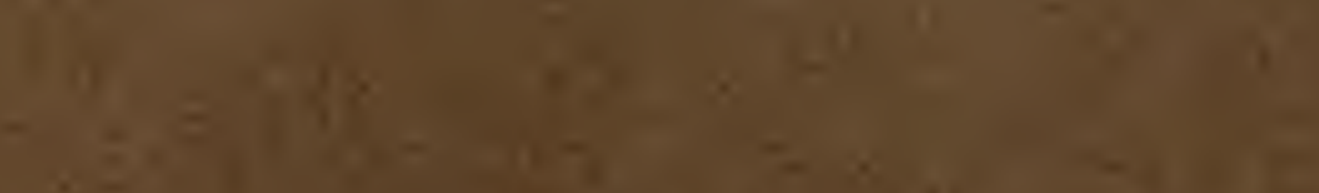

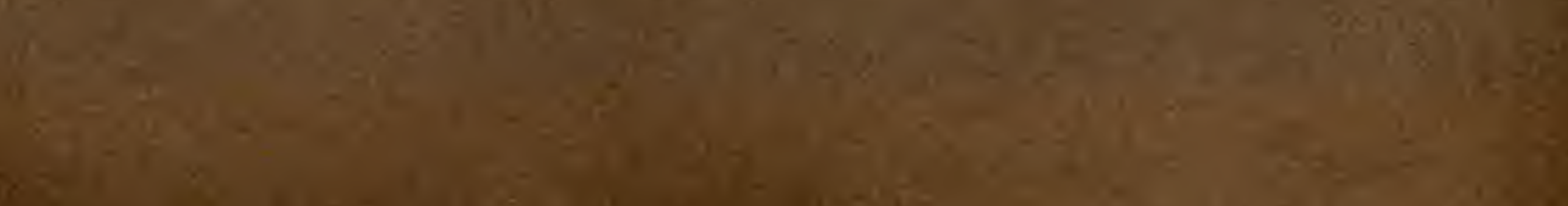

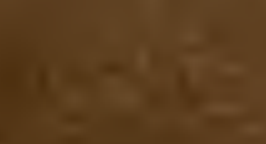




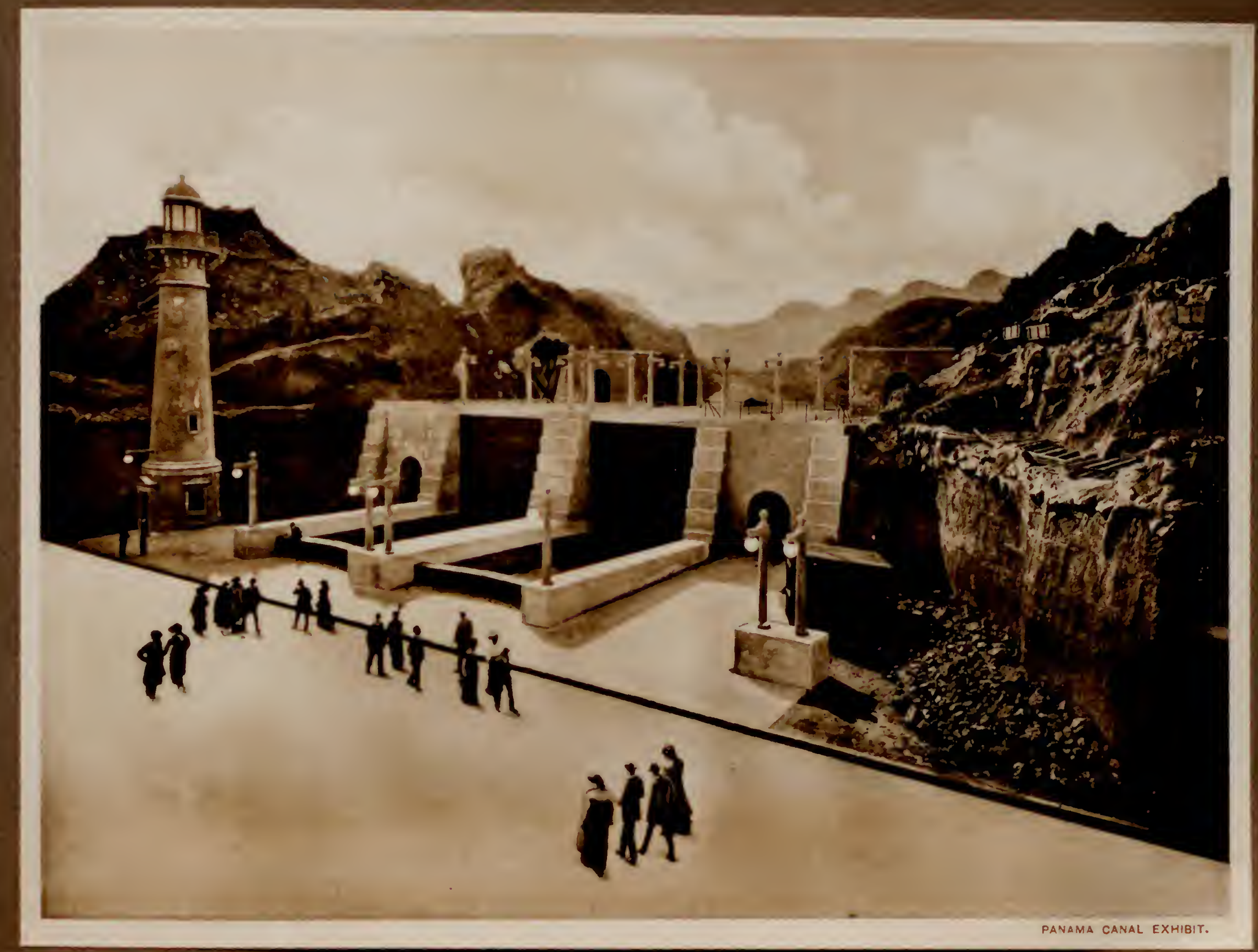




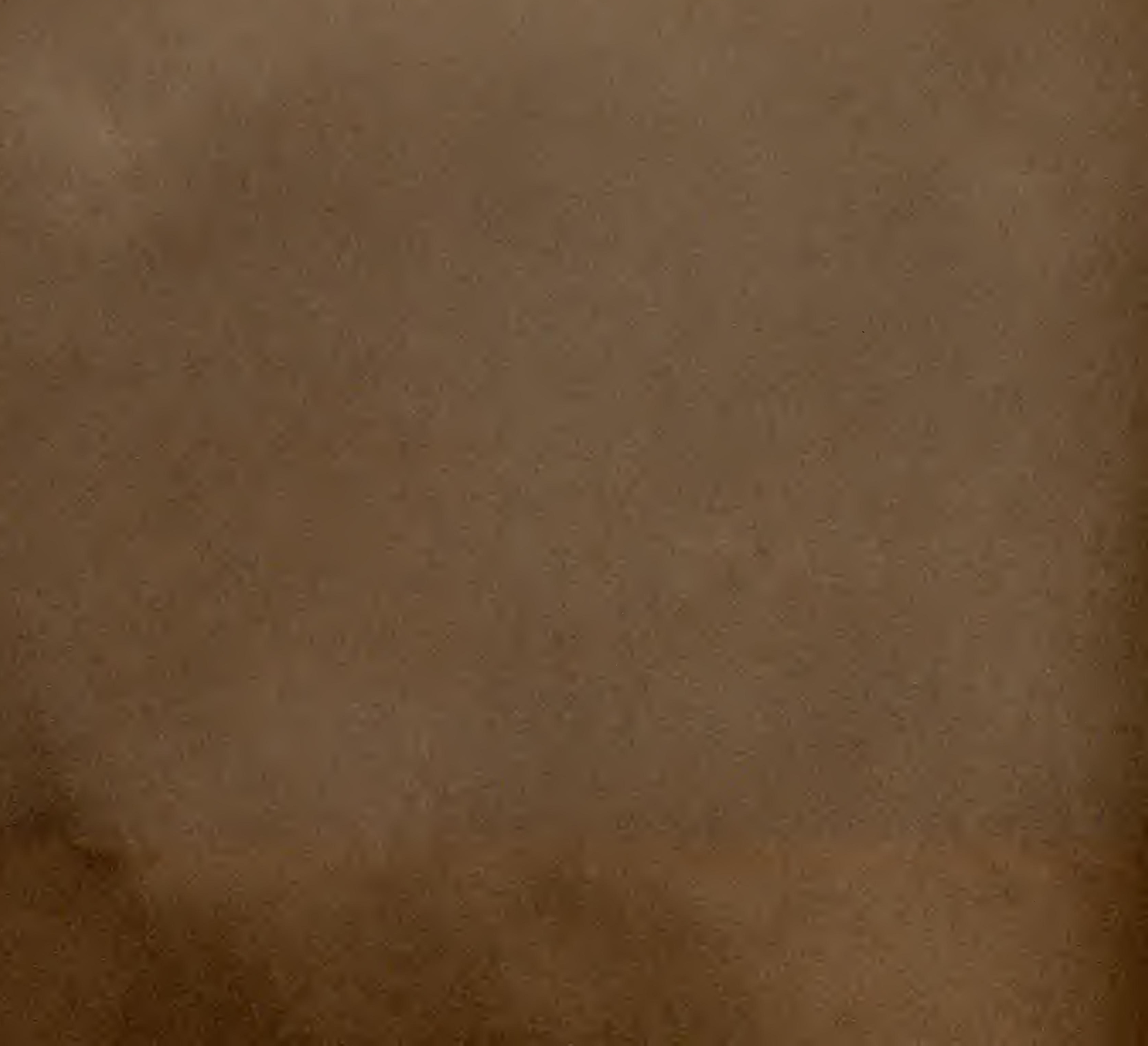




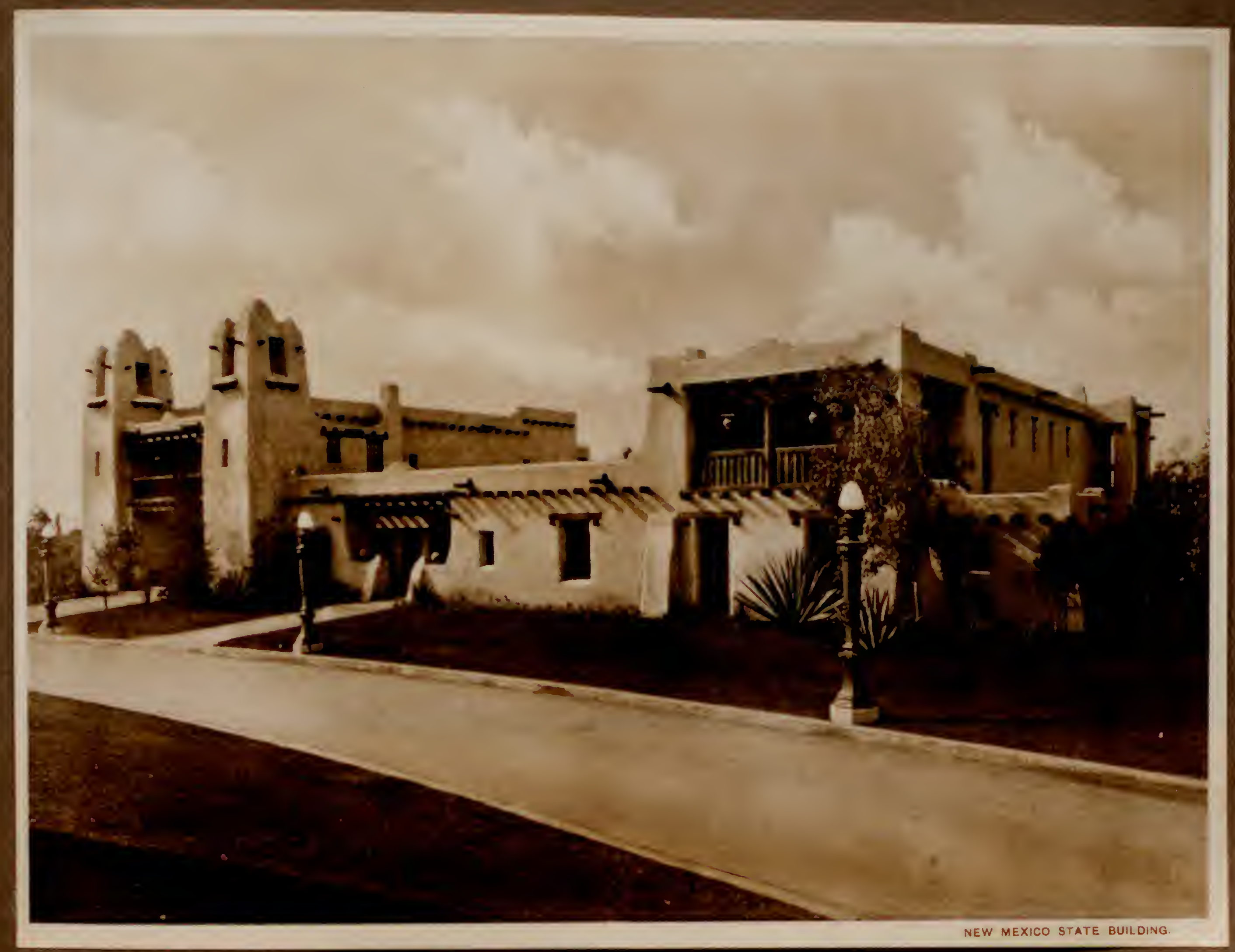





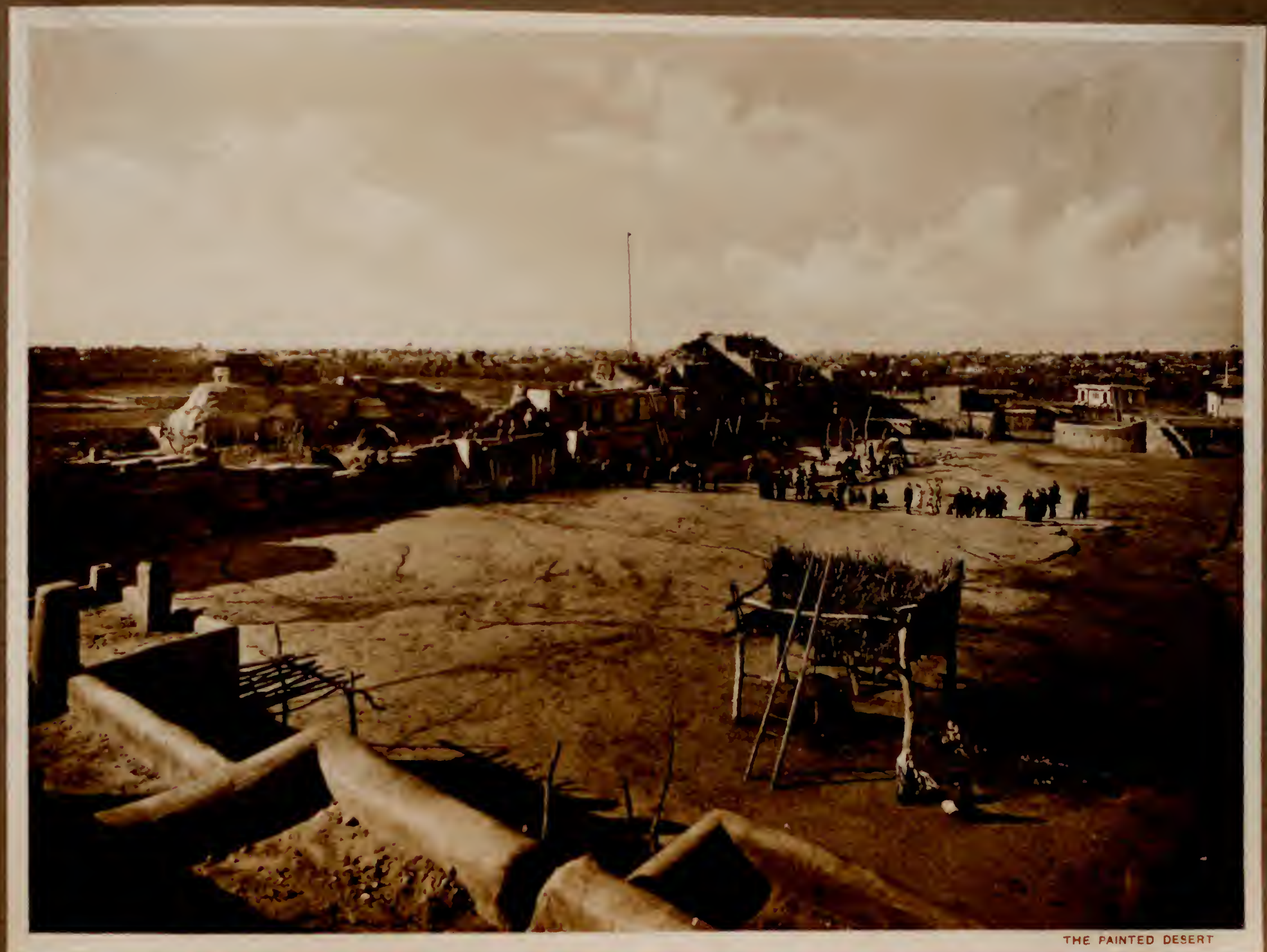




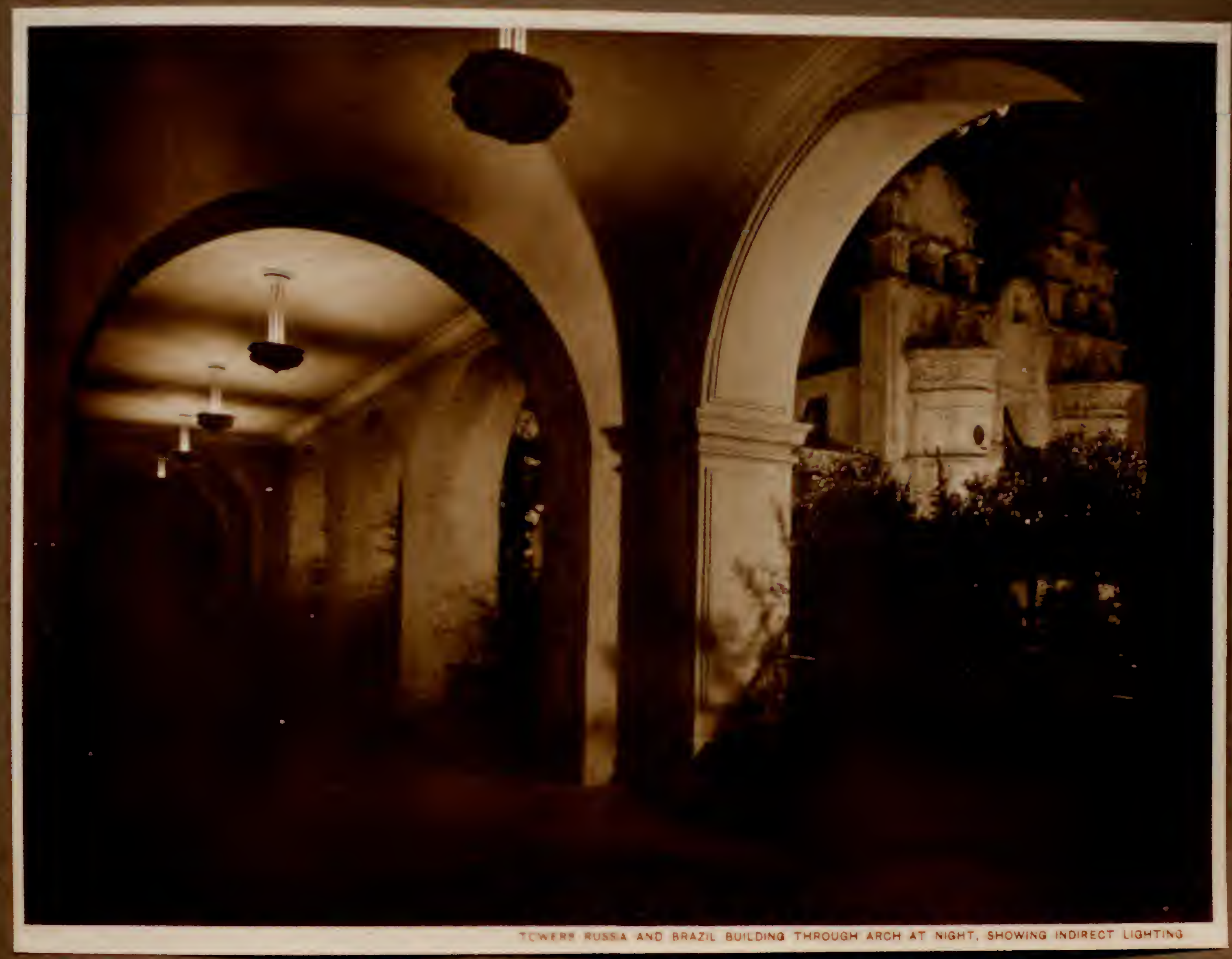





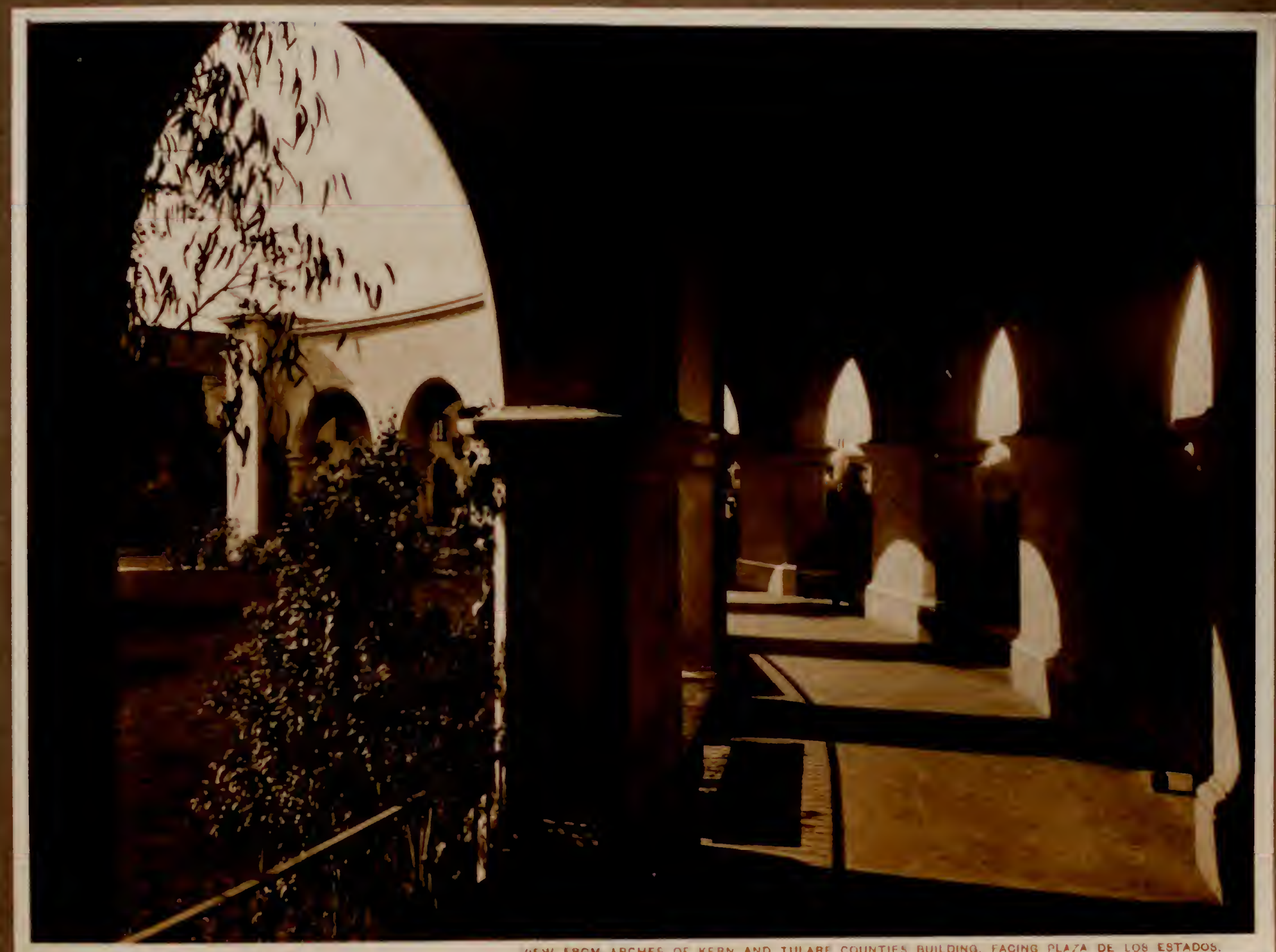




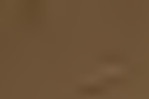




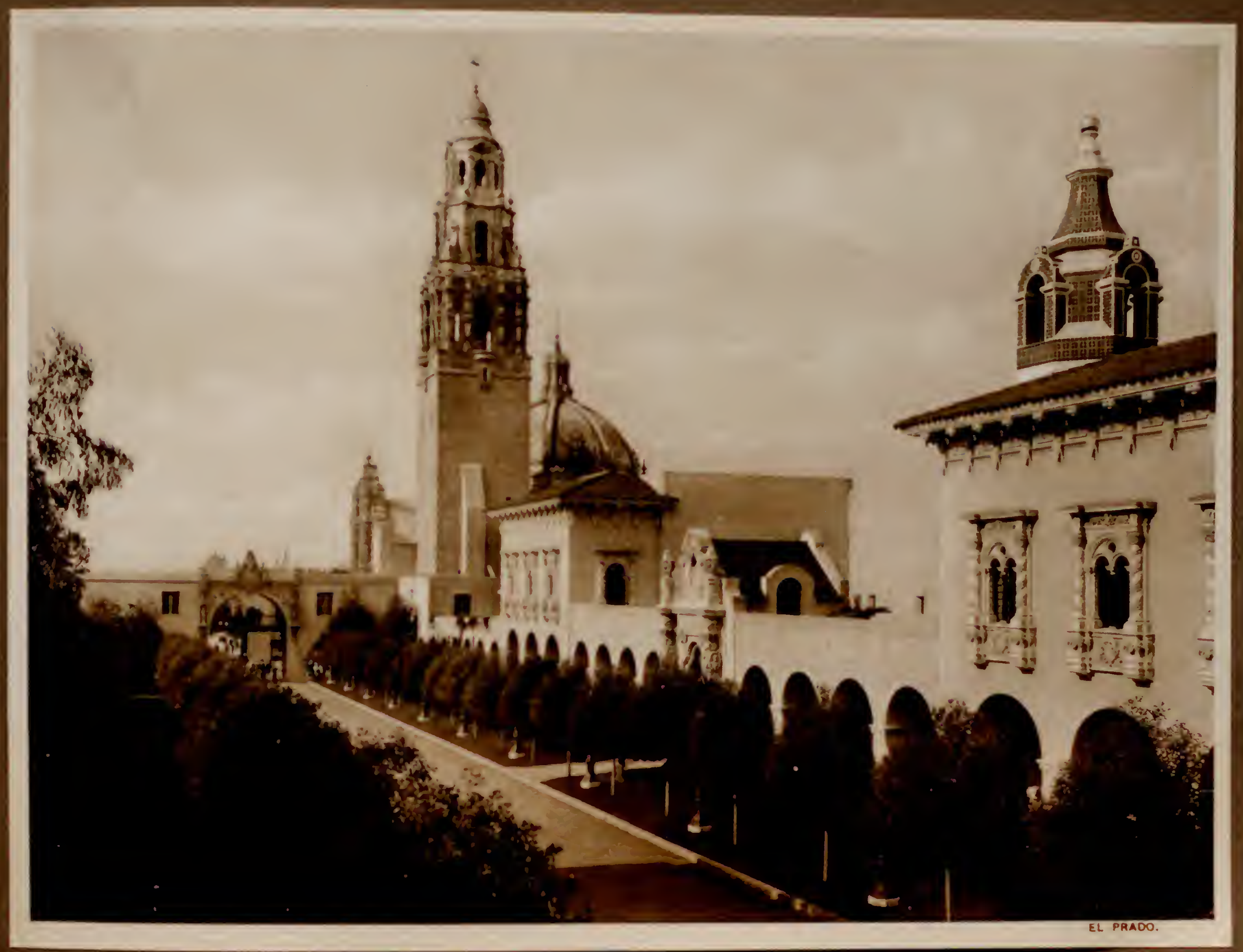




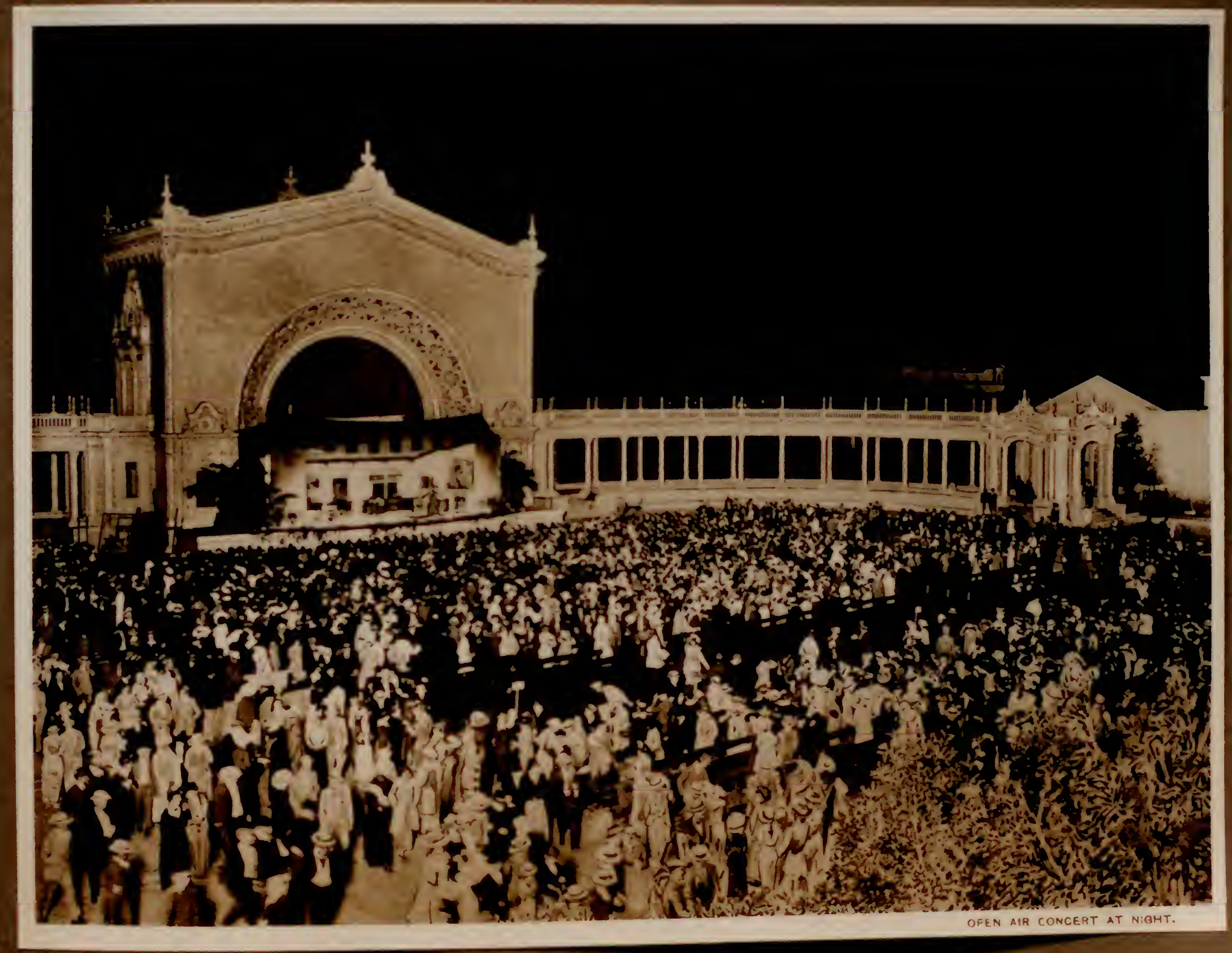


Iis

$x+3=8$ $6 x+2=$

48

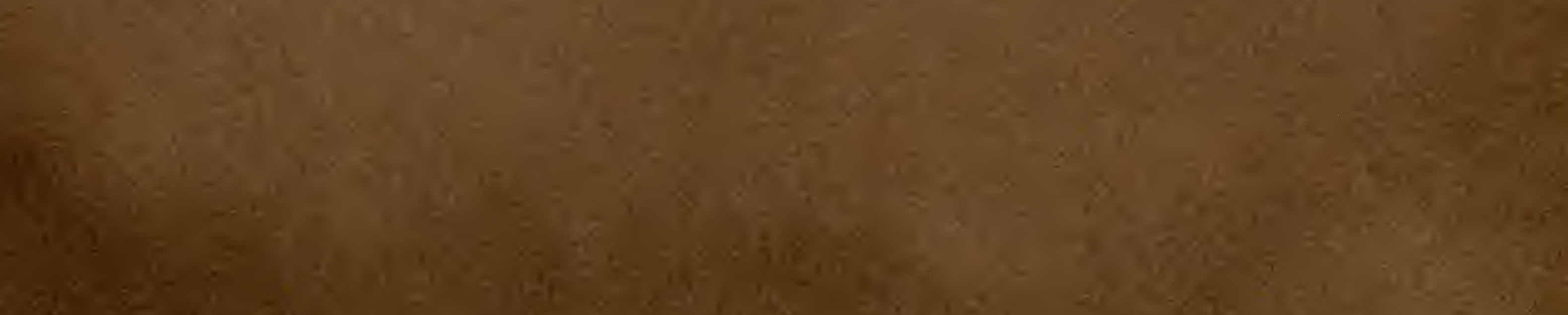

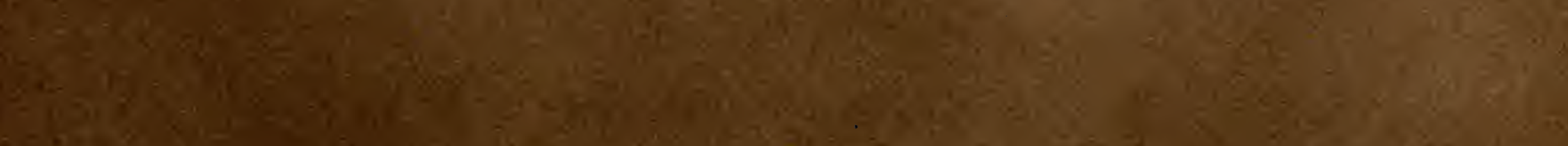




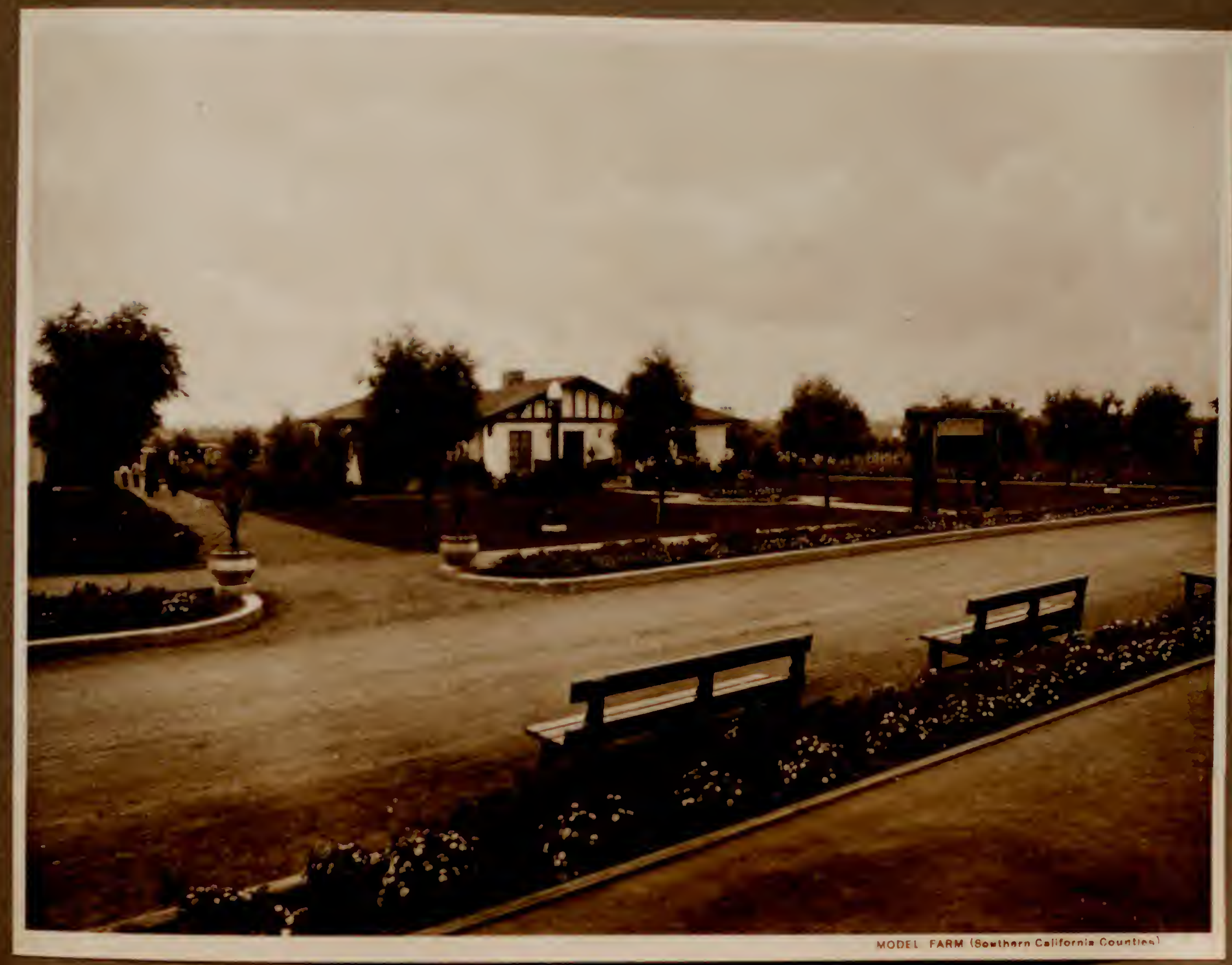





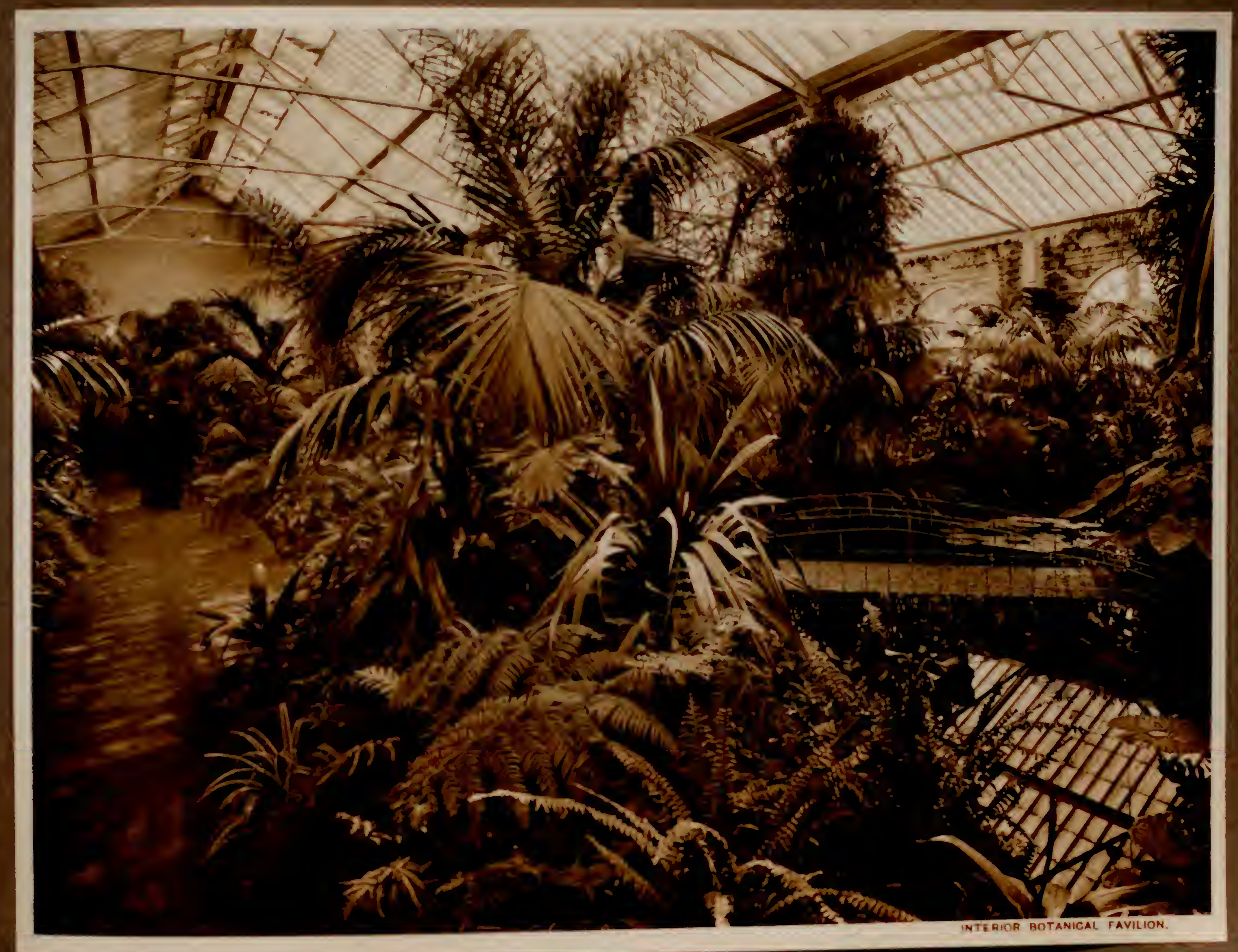


$1-2=8=$ 


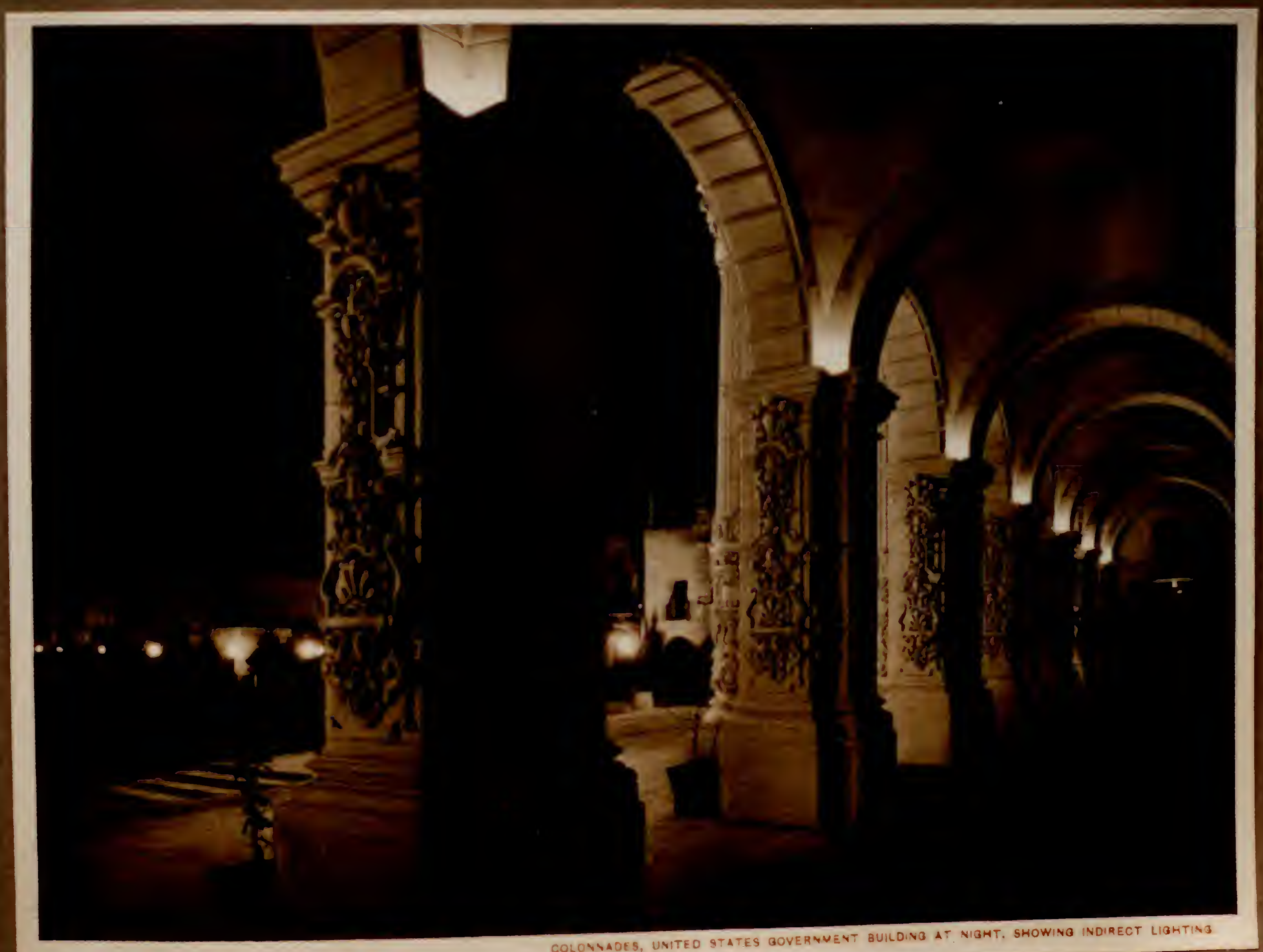





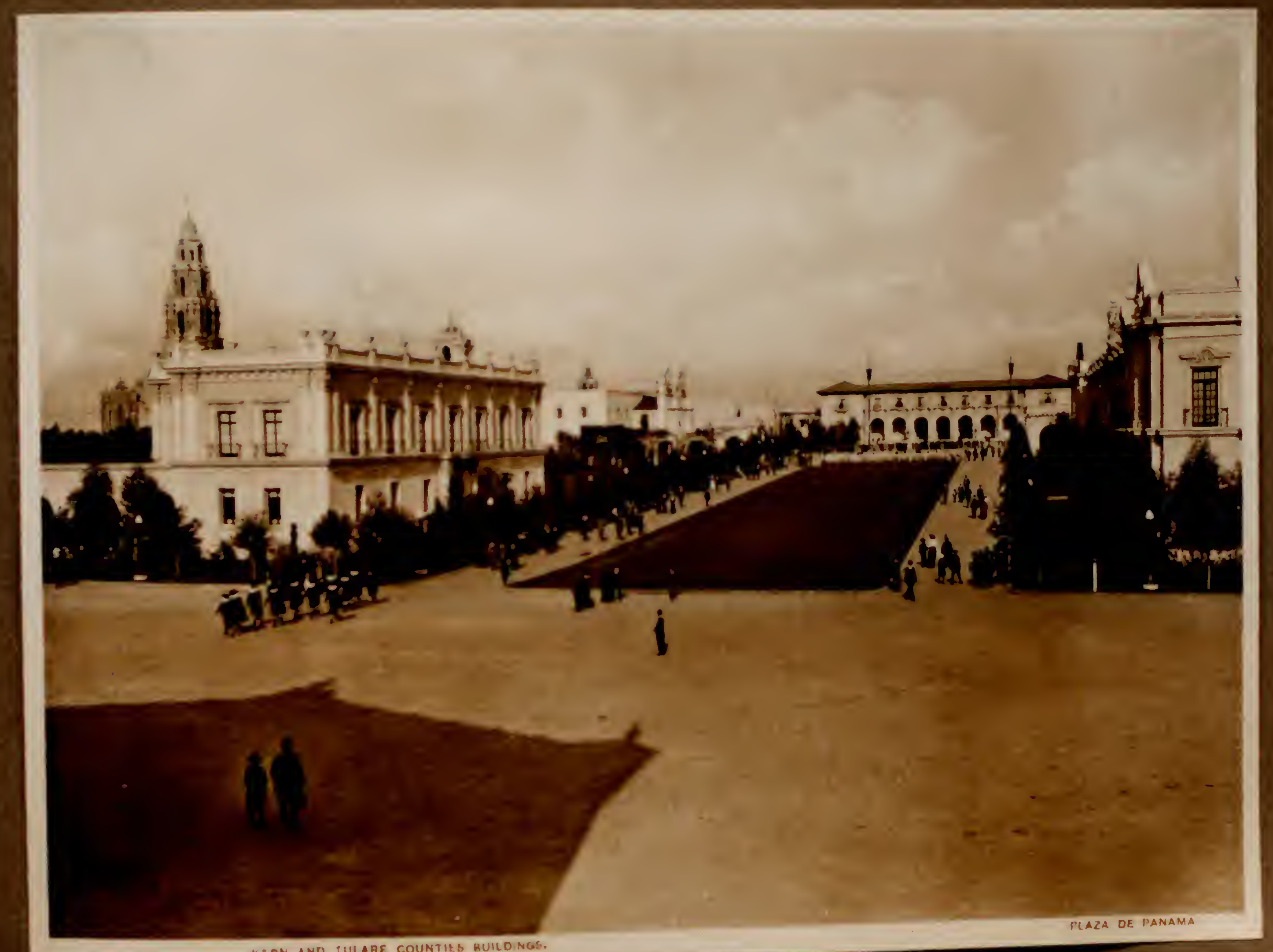




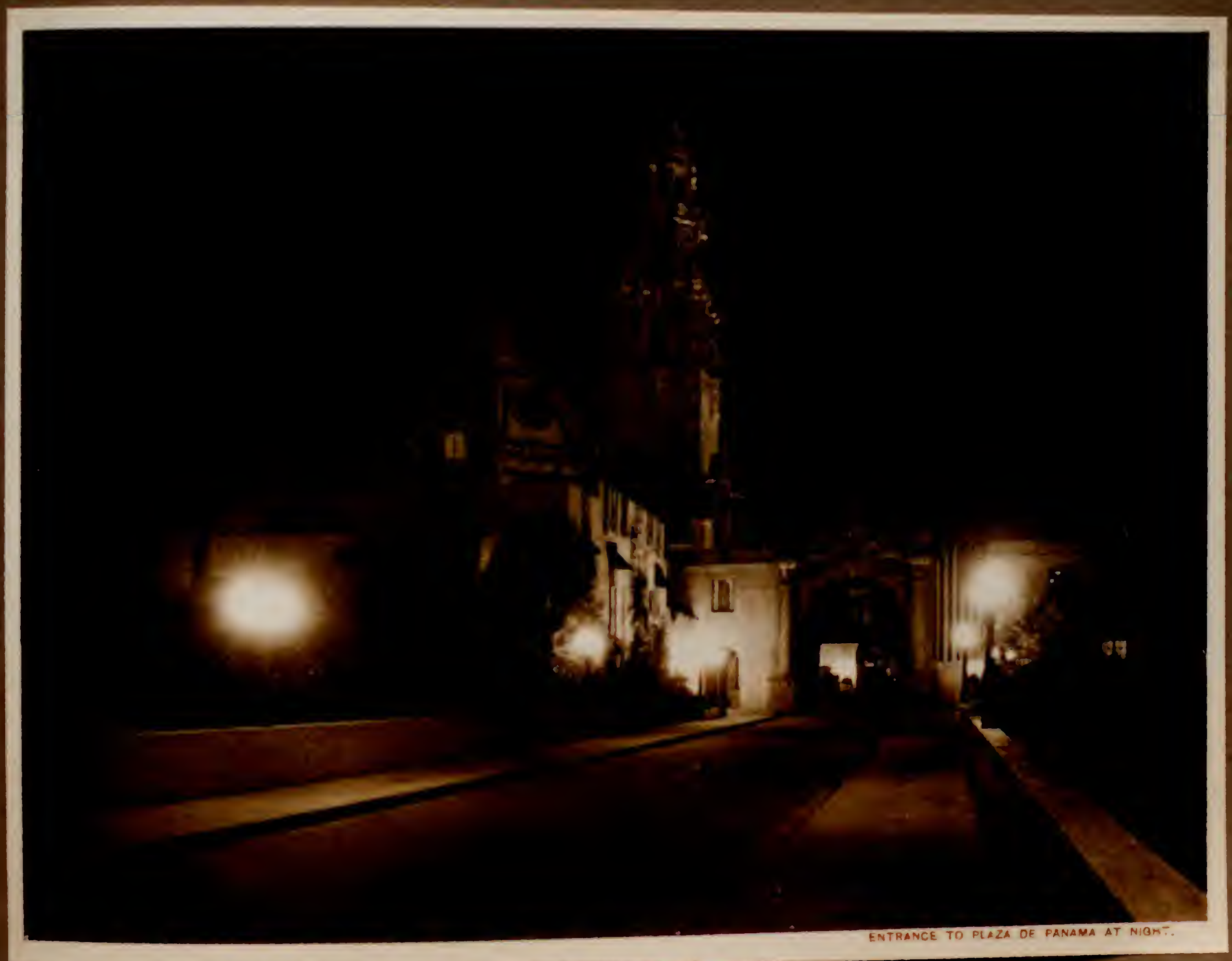





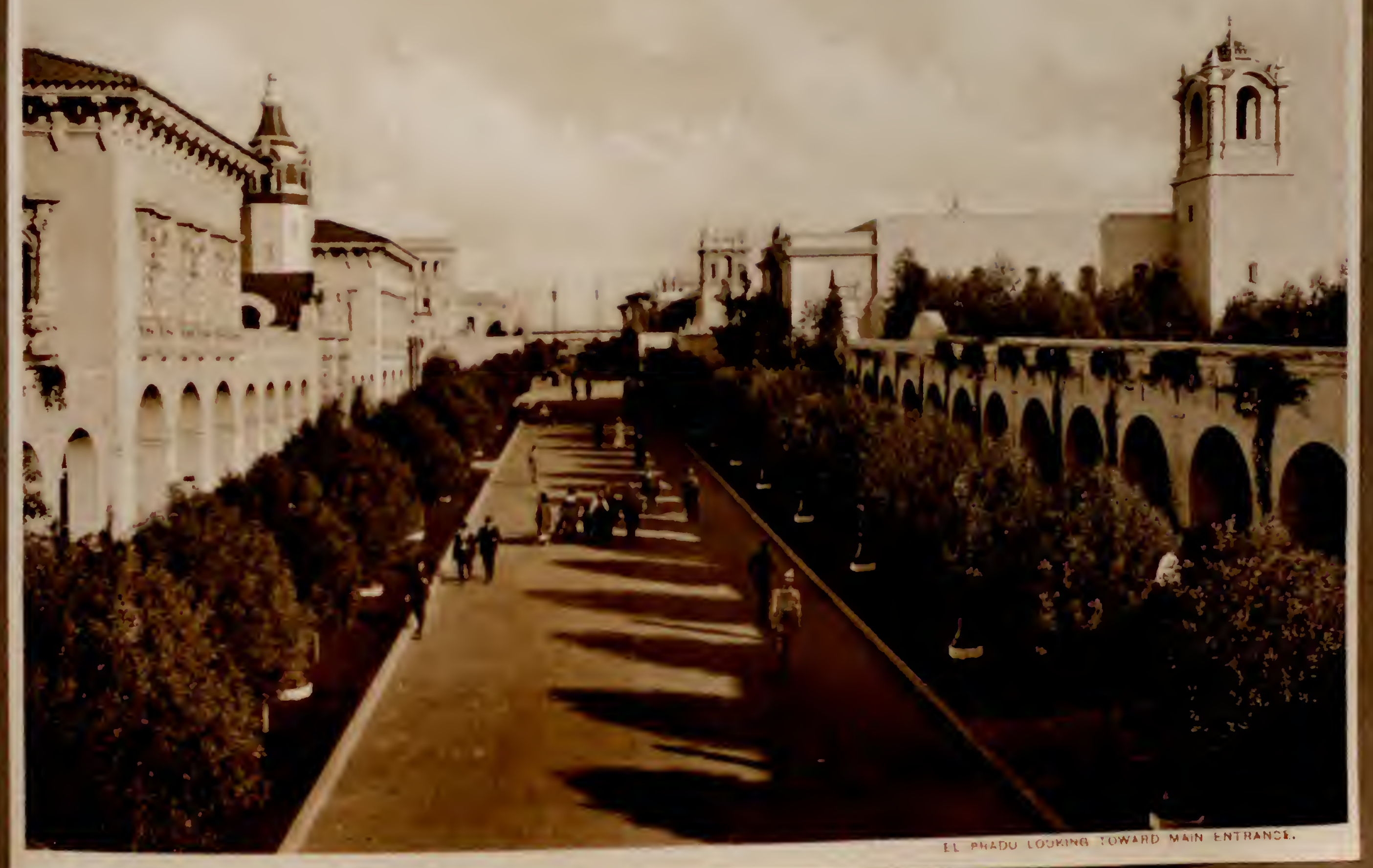





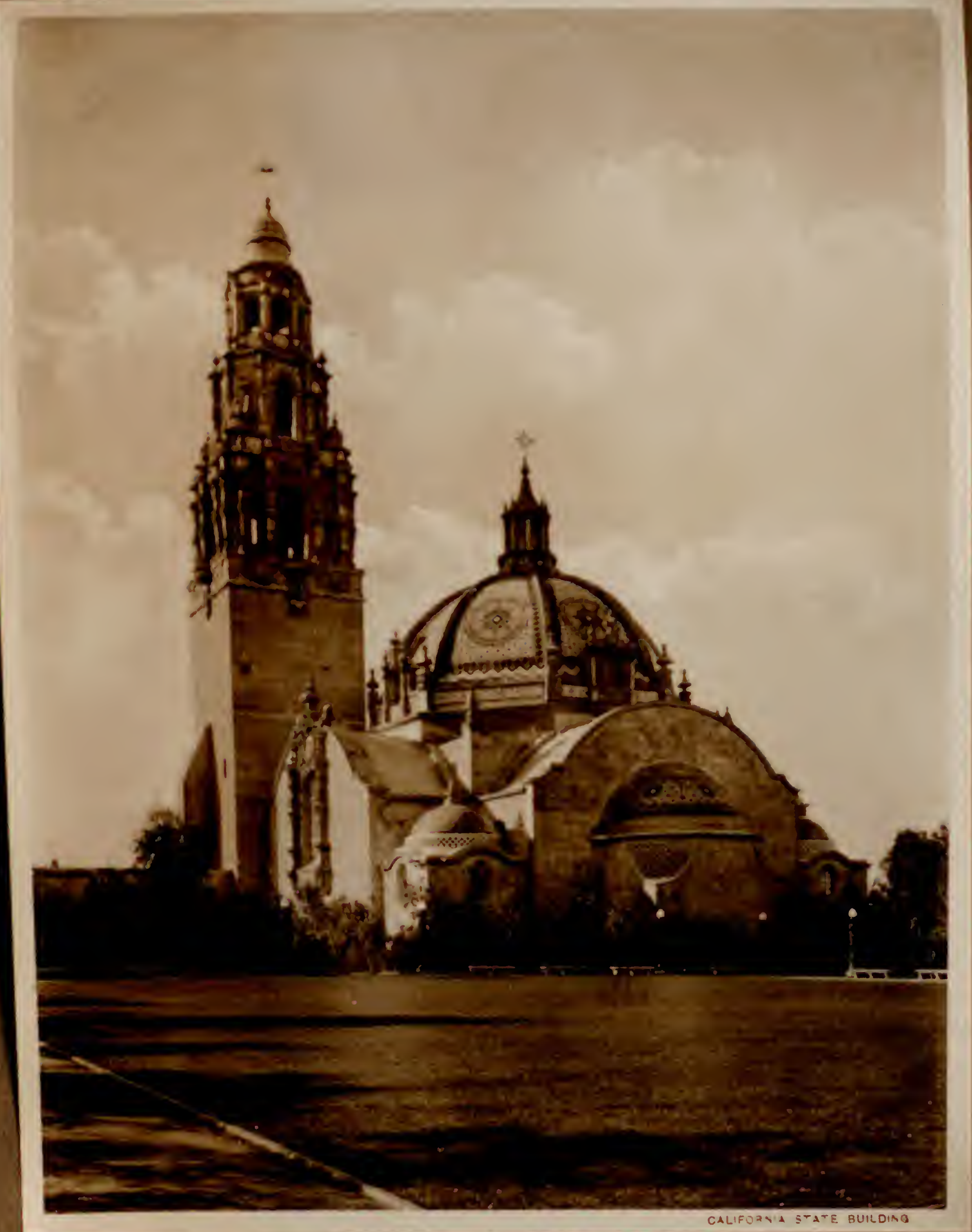





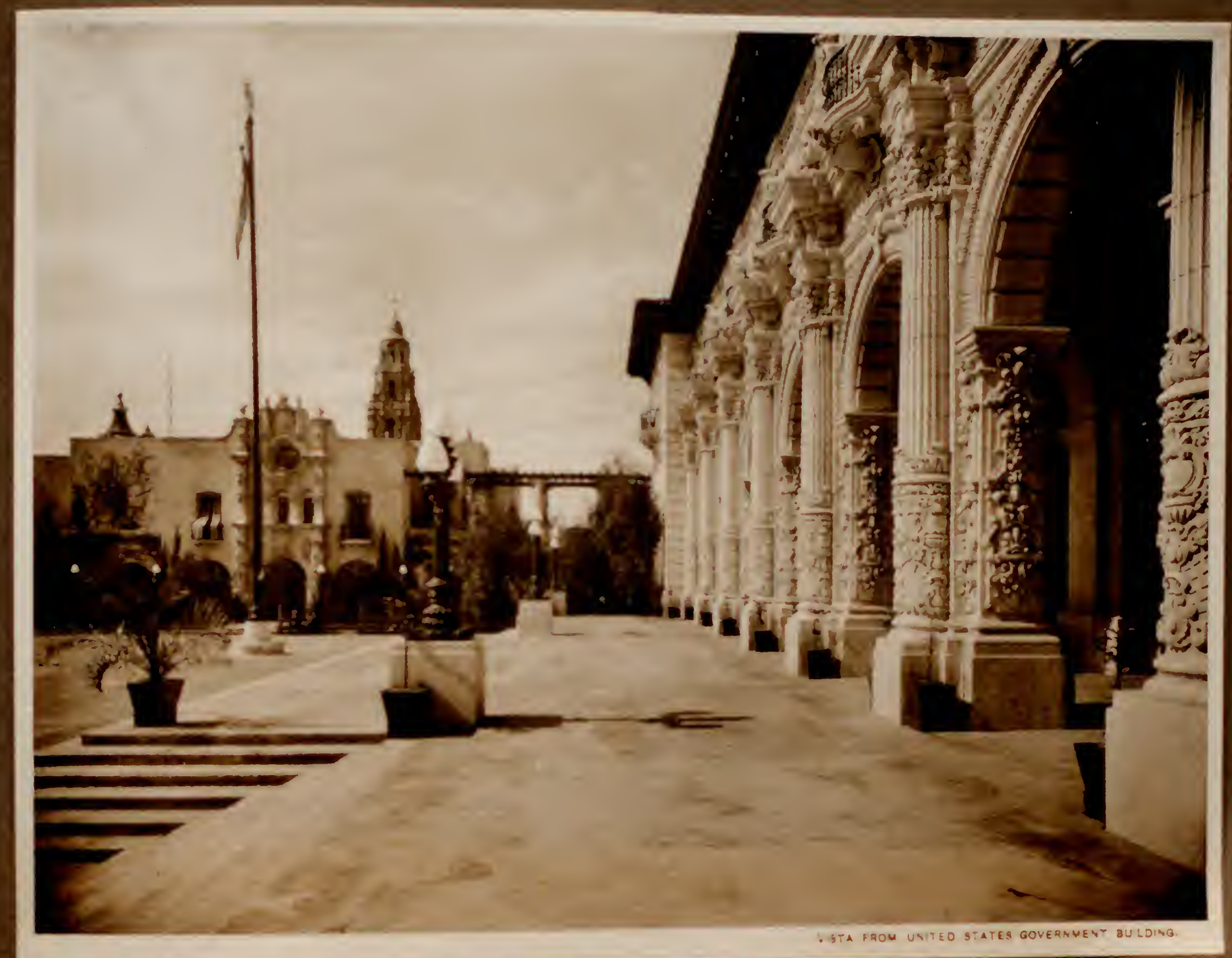





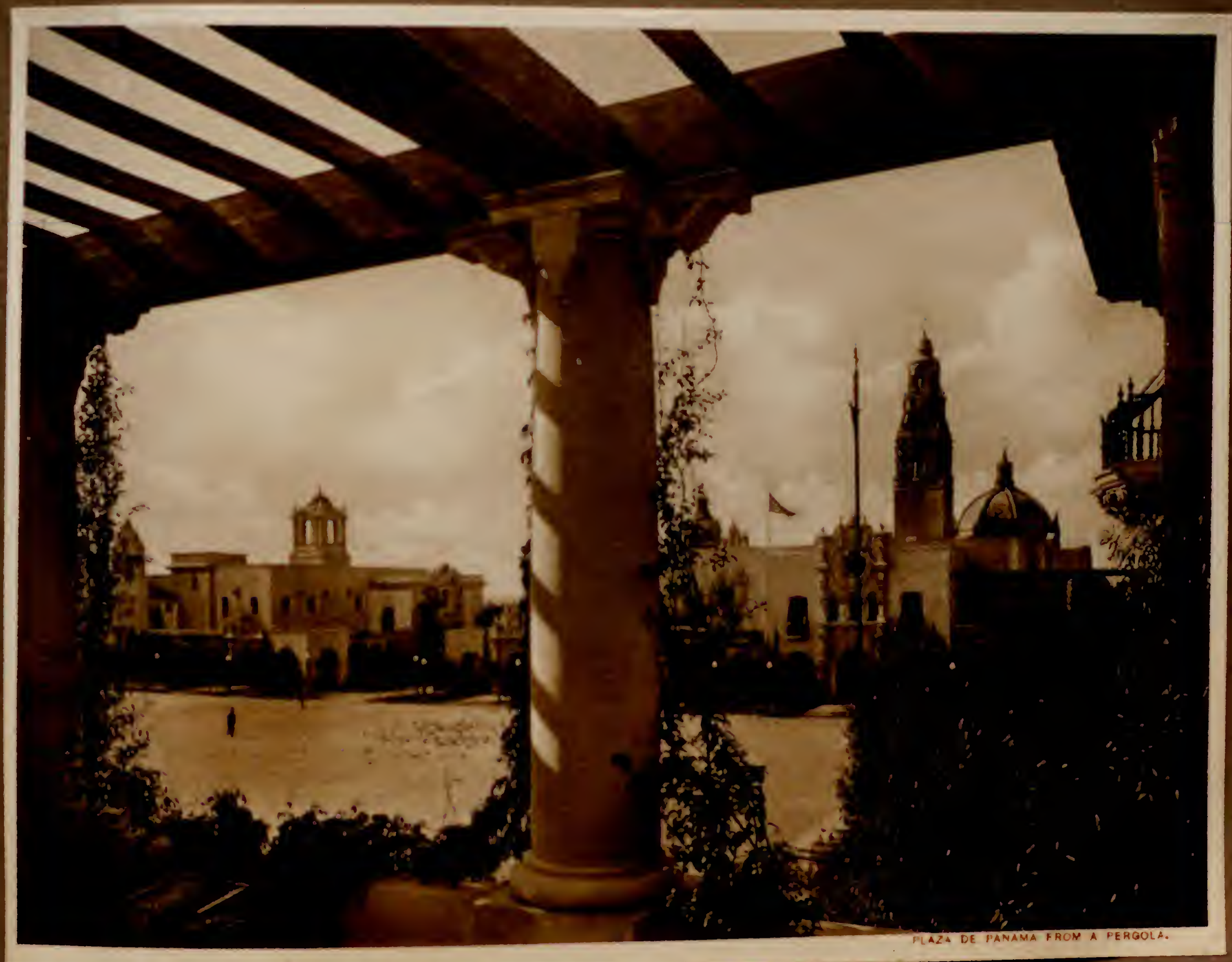





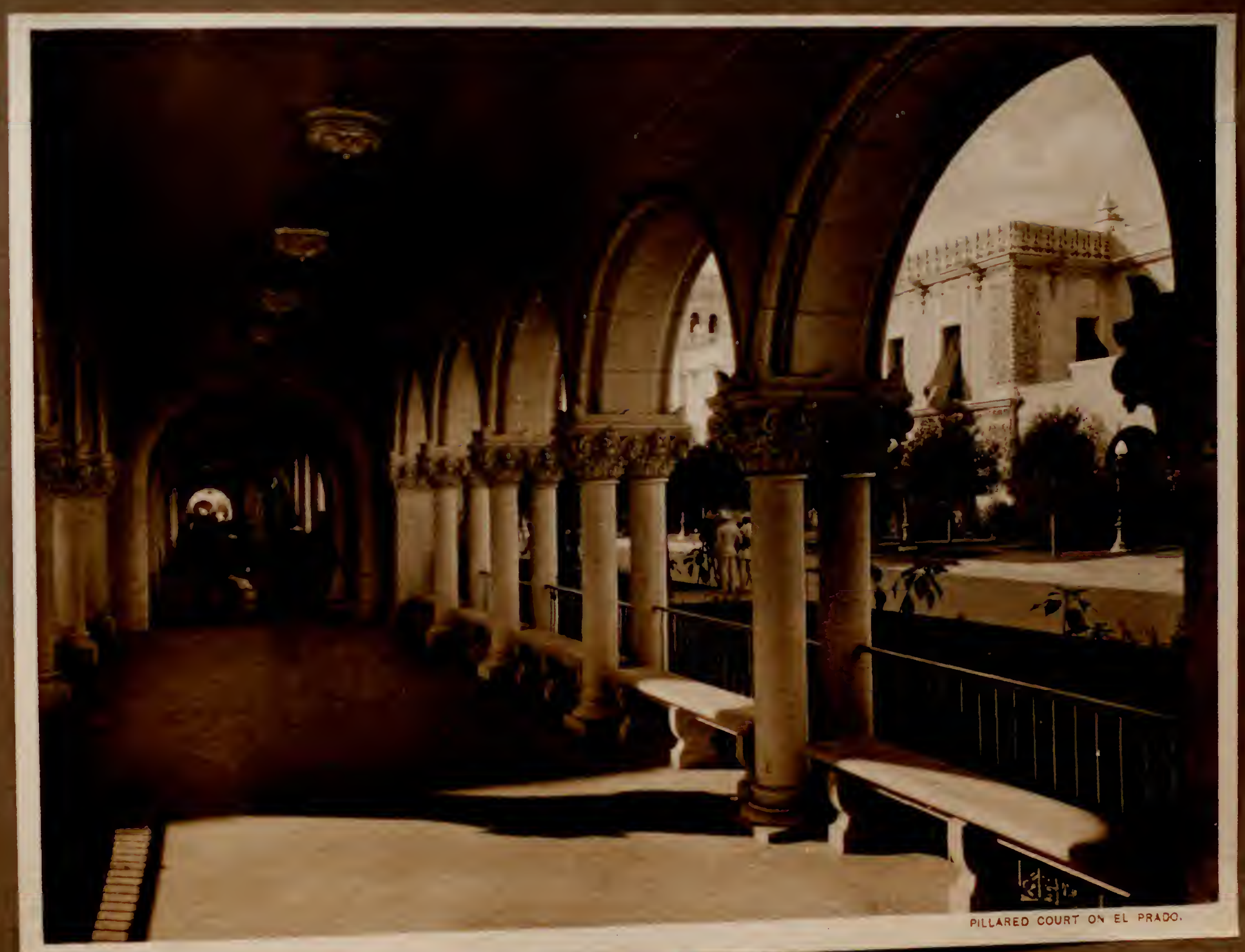





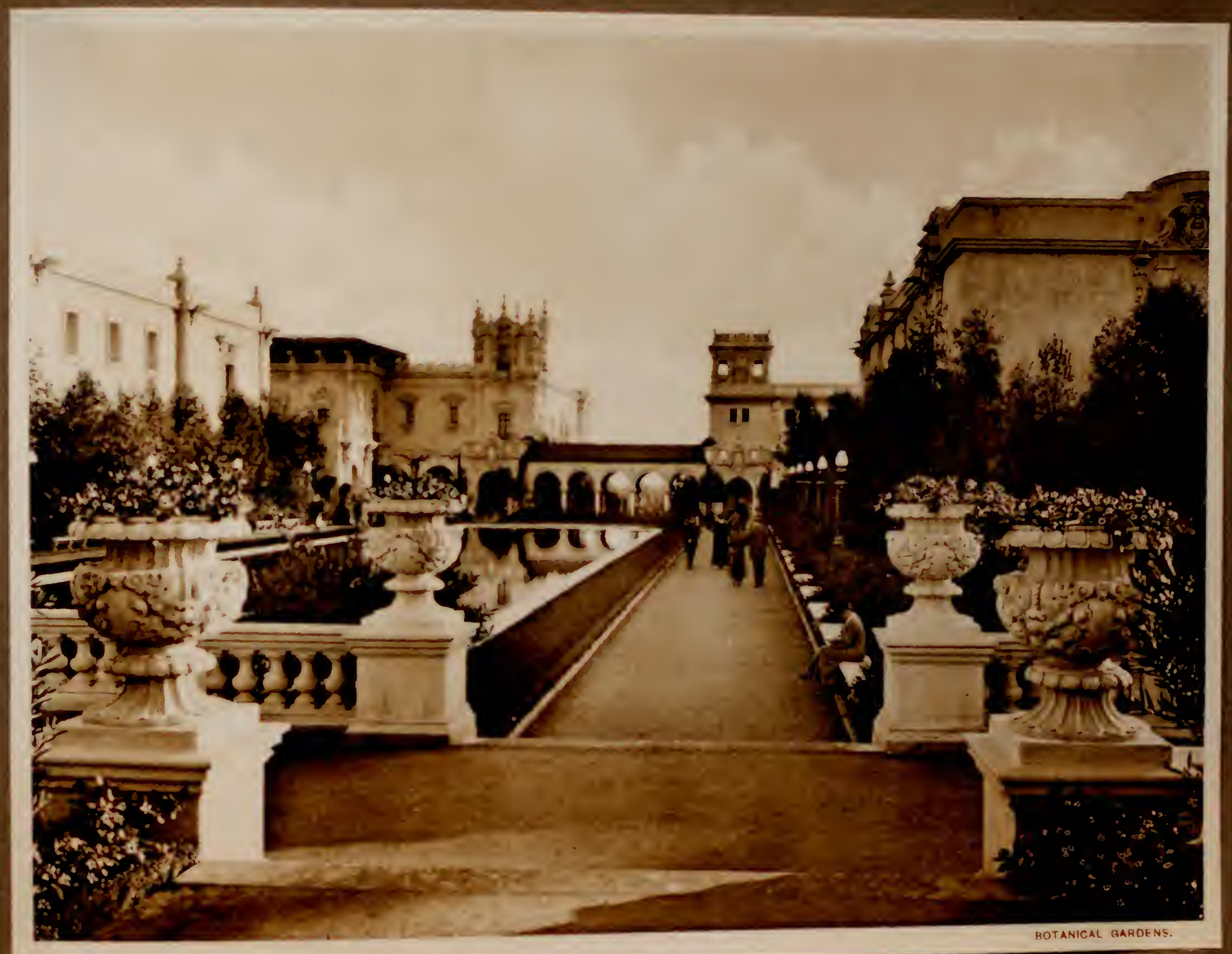





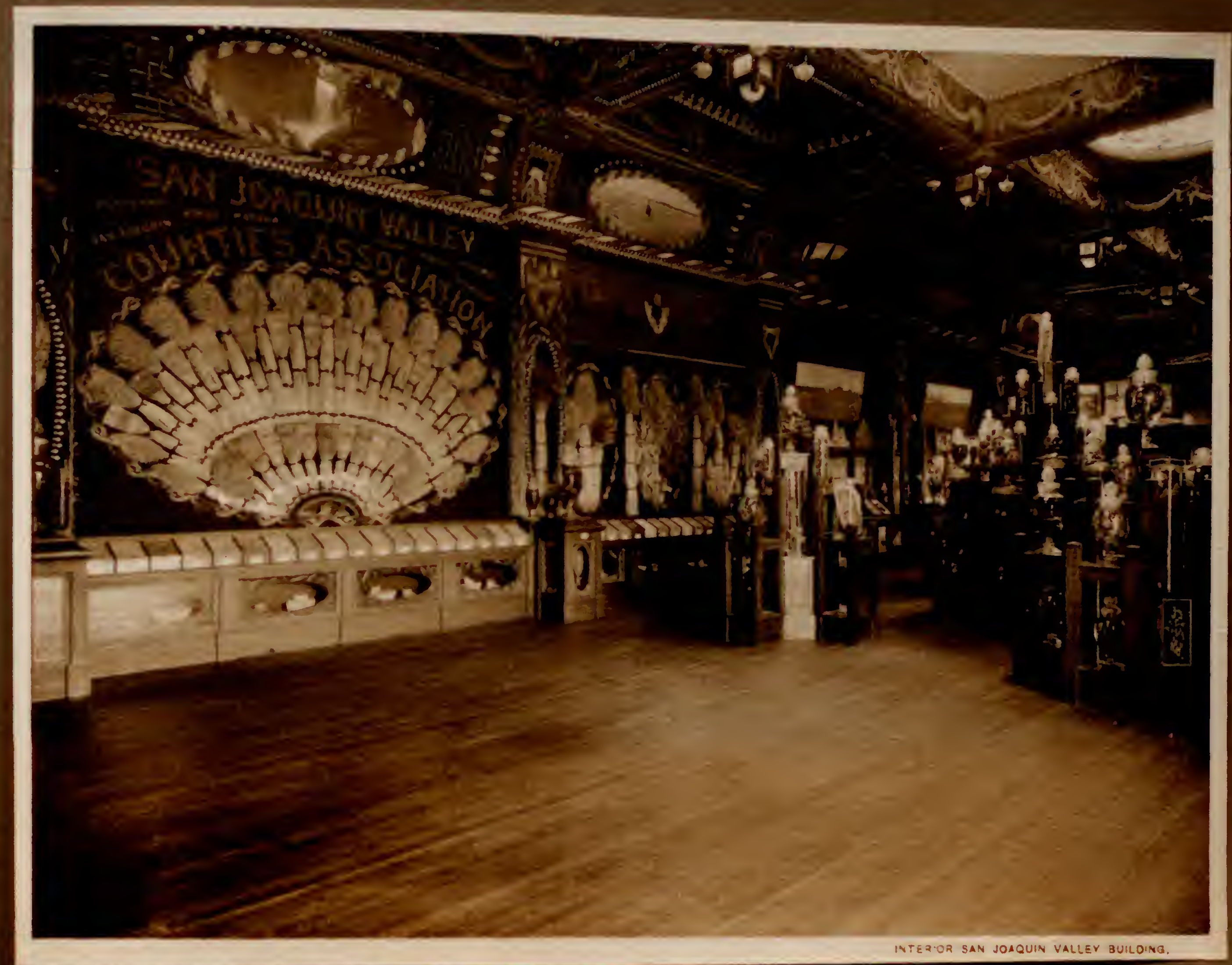





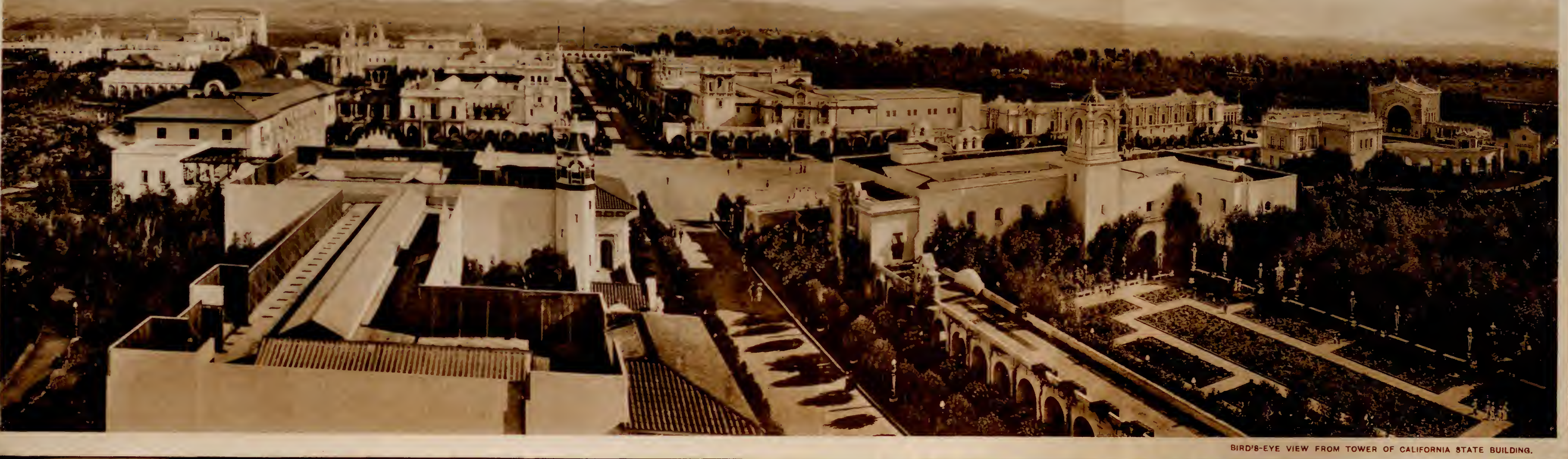


$+$

$3 \times 7=$

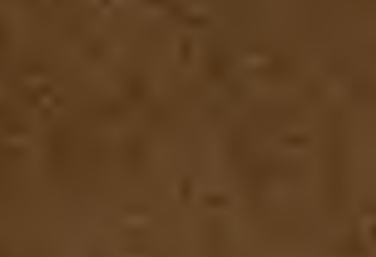

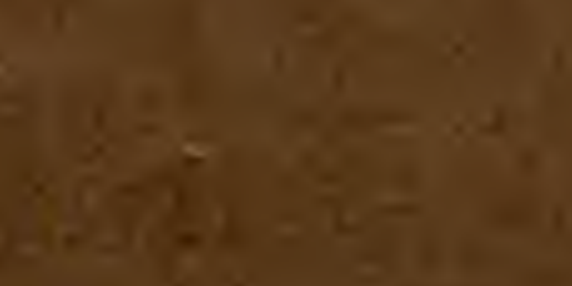


